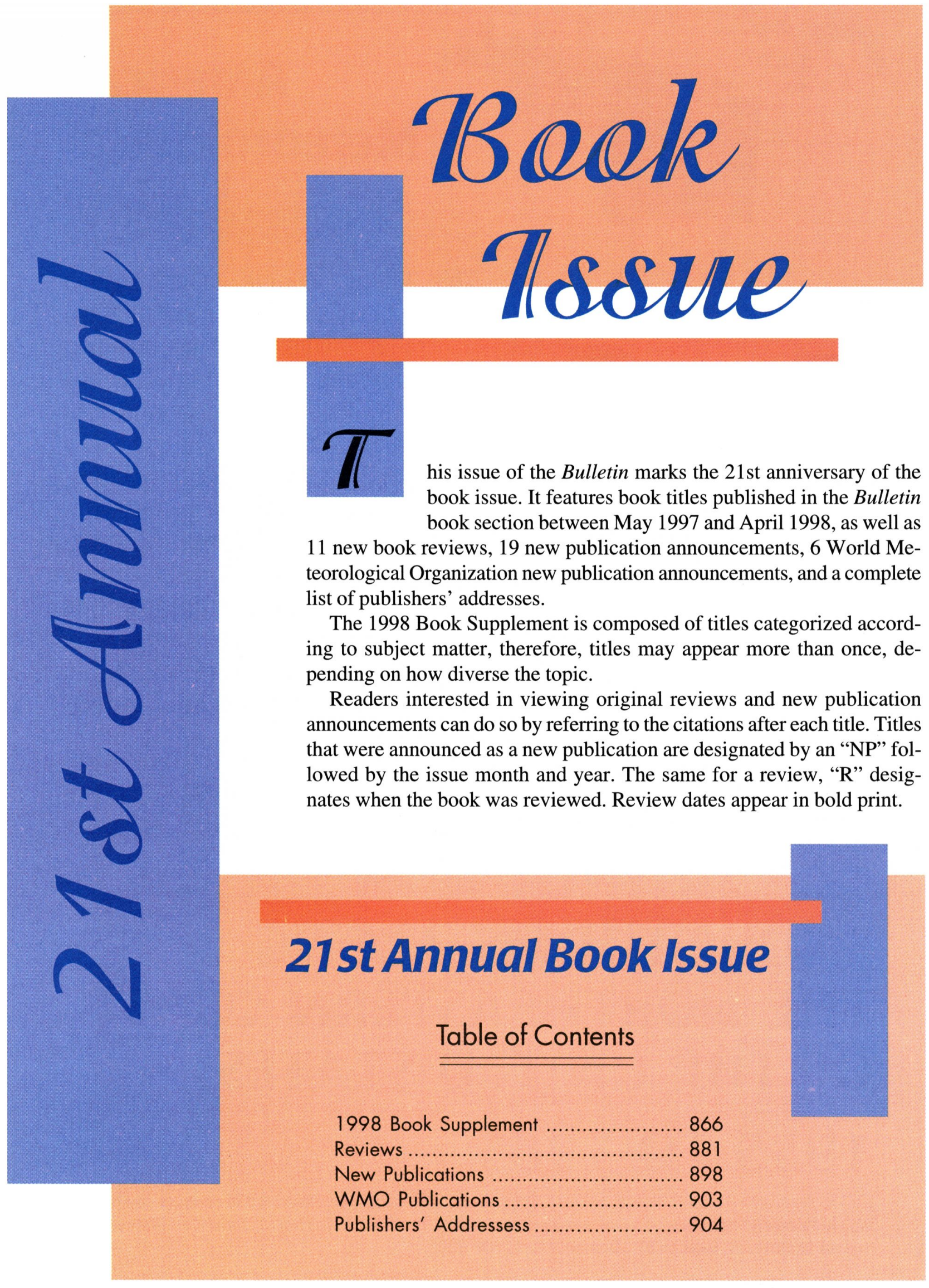




\section{Agricultural Meteorology}

Agricultural Uses of Occult Precipitation. Andres N. Acosta Baladon. 1995. 146 pp. $\$ 20.00$. Paperbound. Agrometeorological Applications Associates. (NP-12/97)

Global Climate Change and Agricultural Production. Fakhri Bazzaz and Wim Sombroek, Eds. 1997.345 pp. \$115.00. Hardbound. John Wiley \& Sons. ISBN 0-47195763-1. (NP-12/97)

\section{Air Quality/Pollution}

Air Pollution Modeling and Its Application XI. Sven-Erik Gryning and Francis A. Schiermeier. 1996. 709 pp. $\$ 159.50$. Hardbound. Plenum Publishing. ISBN 0-306-4538 1-9. (NP-7/97)

Air Pollution V: Modelling, Monitoring and Management. H. Power, T. Tirabassi, and C. A. Brebbia, Eds. 1997. 1036 pp. $\$ 395.00$. Hardbound. Computational Mechanics. ISBN 1-853-12473-7. (NP-2/ 98)

Air Quality. Third Edition. Thad Godish. 1997. 448 pp. \$64.95. Hardbound. CRC Press. ISBN 1-56670-231-3. (NP-1/98)

Guidelines for Use of Vapor Cloud Dispersion Models. Second Edition. Steven R. Hanna and Peter J. Drivas. 1997. 271 pp. \$140.00. Hardbound. American Institute of Chemical Engineers. ISBN 0-81690702-1. (NP-7/97; R-2/98)

Hazy Skies: Weather and the Environment. Jonathan D. W. Kahl. 1998. 64 pp. \$15.95. Hardbound. Lerner Publications. ISBN 0-8225-2530-5. (NP-4/ 98)

Particles in Our Air: Concentrations and Health Effects. Richard Wilson and John Spengler, Eds. 1997.300 pp. $\$ 25.00$. Paperbound. Harvard University Press. ISBN 0-674-24077-4. (NP-5/97)

\section{Antarctic/Arctic \\ Meteorology-Oceanography}

Global Change and Arctic Terrestrial Ecosystems. Walter C. Oechel et al. 1996. 440 pp. \$99.95. Hardbound. SpringerVerlag. ISBN 0-387-94356-0. (NP-6/97)

Physics of the Upper Polar Atmosphere. Asgeir Brekke. 1997. 491 pp. \$44.95. Hardbound. John Wiley \& Sons. ISBN 0-47196018-7. (NP-5/97; R-2/98)

\section{Atmospheric Chemistry}

Biogeochemistry: An Analysis of Global Change. William $\mathrm{H}$. Schlesinger. 1997. 588 pp. \$49.95. Paperbound. Academic Press. ISBN 0-12-625155-X. (NP-5/97; R-8/97)

Chemistry of the Environment. Thomas G. Spiro and William M. Stigliani. 1996. 356 pp. \$59.50. Hardbound. Prentice Hall. ISBN 0-02-415261-7. (NP-5/97; R-9/ 97)

Principles of Atmospheric Physics and Chemistry. Richard Goody. 1995. 324 pp. \$45.00. Hardbound. Oxford University Press. ISBN 0-19-509362-3. (R-5/97)

\section{Biometeorology}

Particles in Our Air: Concentrations and Health Effects. Richard Wilson and John Spengler, Eds. 1997. 300 pp. $\$ 25.00$. Paperbound. Harvard University Press. ISBN 0-674-24077-4. (NP-5/97)

\section{Boundary Layer}

Boundary-Layer Meteorology: 25th Anniversary Volume, 1970-1995.J. R. Garratt and P. A. Taylor, Eds. 1996. 436 pp. $\$ 75.00$. Hardbound. Kluwer Academic Publishers. ISBN 0-7923-4191-0. (NP-7/97) Flows at Large Reynolds Numbers. $\mathrm{H}$. Schmitt, Ed. 1997. 360 pp. \$152.00. Hardbound. Computational Mechanics. ISBN 1-85312-383-8. (NP-1/98) 


\section{Climate Change/Variability}

Annual Report 1996. 1997. 61 pp. $\$ 27.00$. Paperbound. WMO No. 859. World Meteorological Organization. ISBN 92-63-10859-5. (NP-9/97)

Biomass Burning and Global Change. Volume 1. Joel S. Levine, Ed. 1997. 551 pp. $\$ 80.00$. Clothbound. The MIT Press. ISBN 0-262-12201-4. (NP-5/97)

Biomass Burning and Global Change. Volume 2. Joel S. Levine, Ed. 1997. 351 pp. $\$ 70.00$. Clothbound. The MIT Press. ISBN 0-262-12202-2. (NP-5/97)

Climate Change Vulnerability and Adaptation in Asia and the Pacific. Lin Erda et al. 1996. 249 pp. \$115.00. Hardbound. Kluwer Academic Publishers. ISBN 0-7923-4204-6. (NP-7/97)

Climate and Human Health. Laurence S. Kalkstein et al. 1996. 24 pp. \$20.00. Paperbound. WMO No. 843. World Meteorological Organization. ISBN 92-6310843-9. (NP-5/97)

Climate Trend Atlas of Europe: Based on Observations 1891-1990. Christian-D. Schönwiese and Jörg Rapp. 1997. 224 pp. \$112.00. Hardbound. Kluwer Academic Publishers. ISBN 0-79234483-9. (NP-1/98)

Climate Variability, Climate Change and Social Vulnerability in the Semiarid Tropics. Jesse C. Ribot, Antonio R. Magalhães, and Stahis S. Panagides, Eds. 1996. 270 pp. \$74.95. Clothbound. Cambridge University Press. ISBN 0-521. 48074-4. (R-5/97)

Computational Statistics in Climatology. llya Polyak. 1996. 358 pp. \$65.00. Clothbound. Oxford University Press. ISBN 0-19-509999-0. (R-5/97)

Does the Weather Really Matter? The Social Implications of Climate Change. William James Burroughs. 1997. 224 pp. \$24.95. Hardbound. Cambridge University Press. ISBN 0-52 1-56126-4. (NP-12/97; R-3/98)

Earth Under Siege. Richard P. Turco. 1997. 527 pp. \$50.00. Hardbound. Oxford University Press. ISBN 0-19-507286-3. (NP-12/97; R-4/98)
El Niño Southern Oscillation and Climatic Variability. Rob Allan, Janette Lindesay, and David Parker. 1996. 416 pp. $\$ 1$ 10.00. Hardbound and CD-ROM. CSIRO Publishing. ISBN 0-643-05803-6. (NP-5) 97; $\mathbf{R}-\mathbf{7 / 9 7 )}$

European River Activity and Climatic Change during the Lateglacial and Early Holocene. Burkhard Frenzel, Ed. 1995. 226 pp. \$46.50. Paperbound. Gustav Fischer Verlag. ISBN 3-437-308068. $(R-5 / 97)$

Global Change and Arctic Terrestrial Ecosystems. Walter C. Oechel et al. 1996. 440 pp. \$99.95. Hardbound. Springer-Verlag. ISBN 0-387-94356-0. (NP-6/97)

Global Climate Change and Agricultural Production. Fakhri Bazzaz and Wim Sombroek, Eds. 1997. 345 pp. $\$ 115.00$. Hardbound. John Wiley \& Sons. ISBN 0-471-95763-1. (NP-12/97)

The Global Climate System Review: Climate System Monitoring June 1991-November 1993. 1995. 150 pp. $\$ 20.00$. Paperbound. WMO No. 819 . World Meteorological Organization. ISBN 92-63-10819-6. (NP-9/97)

Global Warming: The Complete Briefing. J. Houghton. 1997. 251 pp. $\$ 22.95$. Paperbound. Cambridge University Press. ISBN 0-52 1-62932-2. (NP-4/98)

Global Warming: The Truth behind the Myth. Michael L. Parsons. 1995. 260 pp. $\$ 27.95$. Hardbound. Plenum Publishing. ISBN 0-306-45083-6. (NP-5/97; R-9/ 97)

Laboratory Earth: The Planetary Gamble We Can't Afford to Lose. Stephen H. Schneider. 1997. 174 pp. $\$ 20.00$. Hardbound. BasicBooks. ISBN 0465-07279-8. (NP-5/97; R-7/97)

The Oceans and Climate. Grant R. Bigg. 1996. 266 pp. \$27.95. Paperbound. Cambridge University Press. ISBN 0-52158268-7. (NP-5/97)

Policy Making Global Change: Policy Making in an Era of Global Environmental Change. R. E. Munn, J. W. M. la Rivière, and N. van Lookeren Campagne, Eds. 1996. 225 pp. \$49.50. 
Hardbound. Kluwer Academic Publishers. ISBN 0-7923-3872-3. (NP-5/97; R-6) 97)

Problems of Stable Isotopes in TreeRings, Lake Sediments and PeatBogs as Climatic Evidence for the Holocene. Burkhard Frenzel and Bernhard Stauffer, Eds. 1995. 189 pp. \$47.50. Paperbound. Gustav Fischer Verlag. ISBN 3-437-308 17-3. (R-5/97)

Regional Hydrological Response to Climate Change. J. A. A. Jones et al., Eds. 1996. 440 pp. \$199.00. Hardbound. Kluwer Academic Publishers. ISBN 0-79234329-8. (NP-1/98)

Remote Sensing Calibration Systems: An Introduction. H. S. Chen. 1996. 238 pp. \$64.00. Clothbound. A. Deepak Publishing. ISBN 0-937194-38-7. (NP-7/ 97)

The Role of the Sun in Climate Change. Douglas V. Hoyt and Kenneth H. Schatten. 1997. 279 pp. \$60.00. Clothbound. Oxford University Press. ISBN 0-19-5094131. (NP-10/97)

The Sea Surface and Global Change. Peter S. Liss and Robert A. Duce, Eds. 1996. 496 pp. \$59.95. Hardbound. Cambridge University Press. ISBN 0-521-56273-2. (NP-6/97)

Vulnerability and Adaptation to Climate Change. Joel B. Smith et al., Eds. 1996. 404 pp. \$156.00. Hardbound. Kluwer Academic Publishers. ISBN 0-79234141-4. (R-5/97)

Weather and Water in Cities. 1997. 24 pp. \$20.00. Paperbound. WMO No. 853. World Meteorological Organization. ISBN 92-63-10853-6. (NP-6/97)

WMO Statement on the Status of the Global Climate in 1996. 1997. $11 \mathrm{pp}$. \$15.00. Paperbound. WMO No. 858 . World Meteorological Organization. ISBN 92-63-10858-7. (NP-9/97)

\section{Climate and Environment}

Atlas of the Oceans: Wind and Wave Climate. lan R. Young and Greg J. Holland. 1996. 241 pp. \$960.00. Hardbound and
CD-ROM. Elsevier Science. ISBN 0-08042435-X. (R-7/97)

Biomass Burning and Global Change. Volume 1. Joel S. Levine, Ed. 1997. 551 pp. $\$ 80.00$. Clothbound. The MIT Press. ISBN 0-262-12201-4. (NP-5/97)

Biomass Burning and Global Change. Volume 2. Joel S. Levine, Ed. 1997. 351 pp. $\$ 70.00$. Clothbound. The MIT Press. ISBN 0-262-12202-2. (NP-5/97)

Climate and Human Health. Laurence S. Kalkstein et al. 1996. 24 pp. $\$ 20.00$. Paperbound. WMO No. 843. World Meteorological Organization. ISBN 92-6310843-9. (NP-5/97)

Climate Variability, Climate Change and Social Vulnerability in the Semi-arid Tropics. Jesse C. Ribot, Antonio R. Magalhães, and Stahis S. Panagides, Eds. 1996. 270 pp. \$74.95. Clothbound. Cambridge University Press. ISBN 0-52148074-4. (R-5/97)

Encyclopedia of Climate and Weather. Vols. 1 \& 2. Stephen H. Schneider, Ed. 1996. 929 pp. \$195.00. Clothbound. Oxford University Press. ISBN 0-19-5094859. $(\mathbf{R}-5 / 97)$

Food Security: The Climate Factor. 1996. 11 pp. \$20.00. Paperbound. WMO No. 849. World Meteorological Organization. ISBN 92-63-10849-8. (NP-9/97)

The Global Climate System Review: Climate System Monitoring June 1991-November 1993. 1995. 150 pp. $\$ 20.00$. Paperbound. WMO No. 819 . World Meteorological Organization. ISBN 92 63-10819-6. (NP-9/97)

The Heat Is On: The High Stakes Battle over Earth's Threatened Climate. Ross Gelbspan. 1997. 278 pp. \$23.00. Hardbound. Addison Wesley Longman. ISBN 0-201-13295-8. (R- 10/97)

Lectures Presented at the Twelfth WMO Congress. 1997. 43 pp. $\$ 43.00$. Paperbound. WMO No. 845. World Meteorological Organization. ISBN 92-6310845-5. (NP-9/97) 
The Limnology, Climatology and Paleoclimatology of the East African Lakes. Thomas $C$. Johnson and Eric O. Odada, Eds. 1996. 664 pp. \$140.00. Hardbound. Gordon and Breach Publishers. ISBN 2-88449-234-8. (R-5/ 97)

Our Endangered Planet: Atmosphere. Mary Hoff and Mary M. Rodgers. 1995. 72 pp. \$21.50. Hardbound. Carolrhoda Books. ISBN 0-8225-2509-7. (R-5/97)

Policy Making Global Change: Policy Making in an Era of Global Environmental Change. R. E. Munn, J. W. M. la Rivière, and N. van Lookeren Campagne, Eds. 1996. 225 pp. $\$ 49.50$. Hardbound. Kluwer Academic Publishers. ISBN 0-7923-3872-3. (NP-5/97; R-6/ 97)

Regional Impacts of Global Climate Change: Assessing Change and Response at the Scales That Matter. S. J. Ghan et al., Eds. 1996. 394 pp. \$61.00. Paperbound. Battelle Press. ISBN 1-57477. 017-9. (R-8/97)

Vulnerability and Adaptation to Climate Change. Joel B. Smith et al., Eds. 1996. 404 pp. \$156.00. Hardbound. Kluwer Academic Publishers. ISBN 0-7923-4141-4. (R-5/ 97)

The Weather and Climate of Australia and New Zealand. Andrew Sturman and Nigel Tapper. 1996. 482 pp. \$125.00. Clothbound. Oxford University Press. ISBN 019-553923-0. (R-10/97)

WMO Statement on the Status of the Global Climate in 1996. 1997. $11 \mathrm{pp}$. $\$ 15.00$. Paperbound. WMO No. 858 . World Meteorological Organization. ISBN 92 63-10858-7. (NP-9/97)

\section{Clouds}

Microphysics of Clouds and Precipitation. Second Edition. Hans R. Pruppacher and James D. Klett. 1996. 976 pp. $\$ 290.00$. Hardbound. Kluwer Academic Publishers. ISBN 0-7923-4211-9. (Available in Paperbound. \$99.00. ISBN 0-7923-4409X.) (NP-8/97; R-4/98)
Noctilucent Clouds: Leuchtende Nachtwolken (Theoretical Concepts and Observational Implications). Wilfried Schröder. 1998. 330 pp. $\$ 20.00$. Paperbound. Science Edition. ISSN 0179 5658. (NP-3/98)

\section{Data/Atlases}

Atlas of the Oceans: Wind and Wave Climate. Ian R. Young and Greg J. Holland. 1996. 241 pp. \$960.00. Hardbound and CD-ROM. Elsevier Science. ISBN 0-08-042435-X. (R-7/97)

Climate Trend Atlas of Europe: Based on Observations 1891-1990. Christian-D. Schönwiese and Jörg Rapp. 1997. 224 pp. \$112.00. Hardbound. Kluwer Academic Publishers. ISBN 0-79234483-9. (NP-1/98)

Computational Statistics in Climatology. Ilya Polyak. 1996. 358 pp. \$65.00. Clothbound. Oxford University Press. ISBN 0-19-509999-0. (R-5/97)

EI Niño Southern Oscillation and Climatic Variability. Rob Allan, Janette Lindesay, and David Parker. 1996. 416 pp. $\$ 110.00$. Hardbound and CD-ROM. CSIRO Publishing. ISBN 0-643-05803-6. (NP-5/ 97; R-7/97)

An Introduction to Satellite Image Interpretation. Eric D. Conway and the Maryland Space Grant Consortium. 1997. 242 pp. \$29.95. Paperback (includes CDROM). Johns Hopkins University Press. ISBN O8018-5572-2. (NP-2/98)

Seasonal Simulations CD-ROM. Bernd Dieter Becker. 1997. 4 discs. \$-free. CDROM. European Centre for Medium-Range Weather Forecasts. (NP-9/97)

The Upper Atmosphere: Data Analysis and Interpretation. W. Dieminger, G. K. Hartmann, and R. Leitinger, Eds. 1995. 1032 pp. \$394.00. Hardbound. Springer-Verlag. ISBN 3-540-57562-6. (R-9/97) 


\section{Dynamic Meteorology}

Dynamic Meteorology: A Basic Course.

A. Gorden et al. 1998. 325 pp. $\$ 34.95$.

Paperbound. John Wiley \& Sons. ISBN 0-34059503-5. (NP-4/98)

\section{Environment/Ecology}

Biogeochemistry: An Analysis of Global Change. William H. Schlesinger. 1997. 588 pp. \$49.95. Paperbound. Academic Press. ISBN 0-12-625155-X. (NP-5/97; R-8/97)

Biomass Burning and Global Change. Volume 1. Joel S. Levine, Ed. 1997. 551 pp. $\$ 80.00$. Clothbound. The MIT Press. ISBN 0-262-12201-4. (NP-5/97)

Biomass Burning and Global Change. Volume 2. Joel S. Levine, Ed. 1997. 351 pp. $\$ 70.00$. Clothbound. The MIT Press. ISBN 0-262-12202-2. (NP-5/97)

Chemistry of the Environment. Thomas $G$. Spiro and William M. Stigliani. 1996. 356 pp. $\$ 59.50$. Hardbound. Prentice Hall. ISBN 0-02-415261-7. (NP-5/97; R-9/97)

Climate Change Vulnerability and Adaptation in Asia and the Pacific. Lin Erda et al. 1996. 249 pp. $\$ 115.00$. Hardbound. Kluwer Academic Publishers. ISBN 0-7923-4204-6. (NP-7/97)

Computer Modelling of Seas and Coastal Regions III. J. R. Acinas and C. A. Brebbia, Eds. 1997.350 pp. $\$ 150.00$. Hardbound. Computational Mechanics. ISBN 1-85312499-0. (NP-1/98)

The Endangered Atmosphere: Preserving a Global Commons. Marvin S. Soroos. 1997. 360 pp. \$39.95. Clothbound. University of South Carolina Press. ISBN 1-57003-160-6. (NP-12/97; R- 1/98)

Food Security: The Climate Factor. 1996. 11 pp. \$20.00. Paperbound. WMO No. 849. World Meteorological Organization. ISBN 92-63-10849-8. (NP-9/97)

Global Change and Arctic Terrestrial Ecosystems. Walter C. Oechel et al. 1996. 440 pp. $\$ 99.95$. Hardbound. SpringerVerlag. ISBN 0-387-94356-0. (NP-6/97)
Hazy Skies: Weather and the Environment. Jonathan D. W. Kahl. 1998. 64 pp. \$15.95. Hardbound. Lerner Publications. ISBN 0-8225-2530-5. (NP-4) 98)

The Impact of Desert Dust across the Mediterranean. Stefano Guerzoni and Roy Chester, Eds. 1996. 404 pp. \$180.00. Hardbound. Kluwer Academic Publishers. ISBN 0-7923-4294-1. (NP-9/97; R-3/ 98)

Lectures Presented at the Twelfth WMO Congress. 1997. 43 pp. $\$ 43.00$. Paperbound. WMO No. 845. World Meteorological Organization. ISBN 92-6310845-5. (NP-9/97)

Particles in Our Air: Concentrations and Health Effects. Richard Wilson and John Spengler, Eds. 1997. 300 pp. \$25.00. Paperbound. Harvard University Press. ISBN 0-674-24077-4. (NP-5/97)

Policy Making Global Change: Policy Making in an Era of Global Environmental Change. R. E. Munn, J. $W$. M. la Rivière, and $N$. van Lookeren Campagne, Eds. 1996. 225 pp. $\$ 49.50$. Hardbound. Kluwer Academic Publishers. ISBN 0-7923-3872-3. (NP-5/97; R-6) 97)

Regional Impacts of Global Climate Change: Assessing Change and Response at the Scales That Matter. S. J. Ghan et al., Eds. 1996. 394 pp. \$61.00. Paperbound. Battelle Press. ISBN 1-57477. 017-9. (R-8/97)

Weather and Water in Cities. 1997. 24 pp. $\$ 20.00$. Paperbound. WMO No. 853. World Meteorological Organization. ISBN 92 63-10853-6. (NP-6/97)

Windows on Meteorology: Australian Perspective. Erik K. Webb, Ed. 1997. 342 pp. \$49.95. Paperbound. CSIRO Publishing. ISBN 0-642-06038-3. (NP-2/98)

The World's Water: Is There Enough? 1997. 22 pp. \$20.00. Paperbound. WMO No. 857. World Meteorological Organization. ISBN 92-63-10857-9. (NP-9/97) 
Fluid Dynamics, Mechanics, and Turbulence

Encyclopedia of Climate and Weather. Vols. 1 \& 2. Stephen H. Schneider, Ed. 1996. 929 pp. \$195.00. Clothbound. Oxford University Press. ISBN 0-19-5094859. $(R-5 / 97)$

Flows at Large Reynolds Numbers. $\mathrm{H}$. Schmitt, Ed. 1997.360 pp. \$152.00. Hardbound. Computational Mechanics. ISBN 1-85312-383-8. (NP-1/98)

Gravity Currents in the Environment and the Laboratory. Second Edition. John E. Simpson. 1997. 244 pp. \$74.95. Hardbound. Cambridge University Press. ISBN 0-521-56109-4. (NP-9/97)

Gravity Waves in Water in Finite Depth. J. N. Hunt, Ed. 1997.300 pp. \$129.00. Hardbound. Computational Mechanics. ISBN 1-85312-351-X. (NP-10/97)

Microphysics of Clouds and Precipitation. Second Edition. Hans R. Pruppacher and James D. Klett. 1996. 976 pp. $\$ 290.00$. Hardbound. Kluwer Academic Publishers. ISBN 0-7923-42 1 1-9. (Available in Paperbound. \$99.00. ISBN 0-7923-4409X.) (NP-8/97; R-4/98)

Nonlinear Ocean Waves. W. Perrie, Ed. 1997. 258 pp. \$135.00. Hardbound. Computational Mechanics. ISBN 1-85312414-1. (NP-3/98)

The Ocean Circulation Inverse Problem. Carl Wunsch. 1996. 442 pp. \$54.95. Hardbound. Cambridge University Press. ISBN 0-521-48090-6. (R-4/98)

Ocean Circulation Theory. Joseph Pedlosky. 1996. 464 pp. \$89.95. Hardbound. Springer-Verlag. ISBN 3-540-60489-8. (R1/98)

Principles of Atmospheric Physics and Chemistry. Richard Goody. 1995. 324 pp. $\$ 45.00$. Hardbound. Oxford University Press. ISBN 0-19-509362-3. (R-5/97)

Simulation and Modeling of Turbulent Flows. Thomas B. Gatski, M. Yousuff Hussaini, and John L. Lumley, Eds. 1996. 314 pp. \$39.95. Hardbound. Oxford University Press. ISBN 0-19-510643-1. (NP-5/97; R-8/97)
Singular Spectrum Analysis: A New Tool in Time Series Analysis. James B. Elsner and Anastasios A. Tsonis. 1996. 164 pp. \$49.50. Hardbound. Plenum Publishing. ISBN 0-306-45472-6. (NP-6/97; R-10/ 97)

Turbulence, Coherent Structures, Dynamical Systems and Symmetry. Philip Holmes, John L. Lumley, and Gal Berkooz. 1996. 420 pp. \$69.95. Clothbound. Cambridge University Press. ISBN 0-521-55142-0. (R-12/97)

\section{Forecasting}

Economic Value of Weather and Climate Forecasts. Richard W. Katz and Allan H. Murphy, Eds. 1997. 237 pp. \$49.95. Hardbound. Cambridge University Press. ISBN 0-521-43420-3. (NP-12/97; R-3/98)

Forecasts for Flying. Morley Thomas. 1996. 200 pp. \$14.95. Paperbound. ECW Press. ISBN 1-55022-303-8. (R-5/97)

Lectures Presented at the Twelfth WMO Congress. 1997. 43 pp. $\$ 43.00$. Paperbound. WMO No. 845. World Meteorological Organization. ISBN 92-6310845-5. (NP-9/97)

The Story of the RAAF Meteorological Service. John Joyce. 1997.112 pp. \$unavailable. Paperbound. Australian Bureau of Meteorology. METARCH Papers No. 5. (NP-3/98)

War History of the Australian Meteorological Service in the Royal Australian Air Force April 1941 to July 1946. Thomas Haldane, Ed. 1997.114 pp. $\$$-unavailable. Paperbound. Australian Bureau of Meteorology. METARCH Papers No. 10. (NP-3/98)

Weather Watch: Forecasting the Weather. Jonathan D. W. Kahl. 1996. 72 pp. \$14.95. Hardbound. Lerner Publications. ISBN 0-8225-2529-1. (R-5/97) 


\section{History}

Boundary-Layer Meteorology: 25th Anniversary Volume, 1970-1995. J. R. Garratt and P. A. Taylor, Eds. 1996. 436 pp. \$75.00. Hardbound. Kluwer Academic Publishers. ISBN 0-7923-4191-0. (NP-7/ 97)

The Earth and the Cosmos: The Legacy of Hans Errel. Wilfried Schröder and Hans-Jürgen Treder, Eds. 1997. 382 pp. $\$ 20.00$. Paperbound. Science Edition. ISSN 0179-5658. (NP-1/98)

Everybody Talks About It. A.-Wiin Nielsen. 1997.96 pp. \$-unavailable. Paperbound. The Royal Danish Academy of Sciences and Letters. ISBN 87-7304-288-9. (NP-2/98)

Forecasts for Flying. Morley Thomas. 1996. 200 pp. \$14.95. Paperbound. ECW Press. ISBN 1-55022-303-8. (R-5/97)

The Great Cyclone at St. Lovis and East St. Louis, May 27, 1896 . Julian Curzon, Ed. 1997.429 pp. \$12.95. Paperbound. Southern Illinois University Press. ISBN 0-8093-2124-6. (NP-9/97)

Noctilucent Clouds: Leuchtende Nachtwolken (Theoretical Concepts and Observational Implications). Wilfried Schröder. 1998. 330 pp. \$20.00. Paperbound. Science Edition. ISSN 0179 5658. (NP-3/98)

Skywonkie. Adrian Gordon. 1996. 265 pp. $\$ 7.99$. Paperbound. Minerva Press. ISBN 185863-931-X. (NP-5/97)

The Story of the RAAF Meteorological Service. John Joyce. 1997. 112 pp. \$unavailable. Paperbound. Australian Bureau of Meteorology. METARCH Papers No. 5. (NP-3/98)

Thunder in the Heartland. A Chronicle of Outstanding Weather Events in Ohio. Thomas W. Schmidlin and Jeanne Appelhans Schmidlin. 1996. 373 pp. \$45.00. Clothbound. Kent State University Press. ISBN 087338-549-7. (R- 12/97)

Under the Whirlwind. Arjen and Jerrine Verkaik. 1997. 224 pp. $\$ 25.00$. Paperbound. Whirlwind Books. ISBN 09681537-0-4. (NP-9/97; R-1/98)
War History of the Australian Meteorological Service in the Royal Australian Air Force April 1941 to July 1946. Thomas Haldane, Ed. 1997. 114 pp. \$-unavailable. Paperbound. Australian Bureau of Meteorology. METARCH Papers No. 10. (NP-3/98)

Windows on Meteorology: Australian Perspective. Erik K. Webb, Ed. 1997. 342 pp. $\$ 49.95$. Paperbound. CSIRO Publishing. ISBN 0-642-06038-3. (NP-2/ 98)

\section{Hydrology}

Agricultural Uses of Occult Precipitation. Andres N. Acosta Baladon. 1995. 146 pp. \$20.00. Paperbound. Agrometeorological Applications Associates. (NP-12/97)

Climate Variability, Climate Change and Social Vulnerability in the Semiarid Tropics. Jesse C. Ribot, Antonio R. Magalhães, and Stahis S. Panagides, Eds. 1996. 270 pp. \$74.95. Clothbound. Cambridge University Press. ISBN 0-521. 48074-4. (R-5/97)

Computer Models of Watershed Hydrology. Vijay P. Singh, Ed. 1995. 1144 pp. \$95.00. Hardbound. Water Resources Publications. ISBN 0-918334-91-8. (NP-8/ 97; R-11/97)

Distributed Hydrological Modelling. Michael B. Abbott and Jens Christian Refsgaard, Eds. 1996.321 pp. \$158.00. Hardbound. Kluwer Academic Publishers. ISBN 0-7923-4042-6. (NP-6/97; R-2/ 98)

Geographical Information Systems in Hydrology. Vijay P. Singh and $M$. Fiorentino, Eds. 1996. 464 pp. \$219.00. Hardbound. Kluwer Academic Press. ISBN 07923-4226-7. (R-7/97)

Global Continental Palaeohydrology. K. J. Gregory, L. Starkel, and V. R. Baker, Eds. 1996. 400 pp. \$132.00. Clothbound. John Wiley \& Sons. ISBN 0-47 1-95420-9. (NP5/97; R-4/98) 
Hydrology of Disasters. Vijay P. Singh. 1996. 456 pp. \$215.00. Hardbound. Kluwer Academic Publishers. ISBN 0-79234092-2. (NP-5/97; R-11/97)

Introduction to Geostatistics: Applications in Hydrogeology. P. K. Kitanidis. 1997. 249 pp. \$29.95. Paperbound. Cambridge University Press. ISBN 0-52 1-58747-6. (NP-1/98)

Microphysics of Clouds and Precipitation. Second Edition. Hans R. Pruppacher and James D. Klett. 1996. 976 pp. $\$ 290.00$. Hardbound. Kluwer Academic Publishers. ISBN 0-7923-42 1 1-9. (Available in Paperbound. \$99.00. ISBN 07923-4409-X.) (NP-8/97; R-4/98)

Regional Frequency Analysis. J. R. M. Hosking and J. R. Wallis. 1997. 224 pp. $\$ 69.95$. Hardbound. Cambridge University Press. ISBN 0-52 1-43045-3. (NP-1/98)

Regional Hydrological Response to Climate Change. J. A. A. Jones et al., Eds. 1996.440 pp. $\$ 199.00$. Hardbound. Kluwer Academic Publishers. ISBN 0-7923-4329-8. (NP-1/98)

River Ice Jams. Spyros Beltaos, Ed. 1995. 390 pp. $\$ 58.00$. Hardbound. Water Resources Publications. ISBN 0-91 8334-87-X. (NP-9/ 97; R-10/97)

Time and the River. G. W. Kite, Ed. 1995. 374 pp. \$58.00. Hardbound. Water Resources Publications, Inc. ISBN 0-91833497-7. (NP-8/97)

Weather and Water in Cities. 1997. 24 pp. \$20.00. Paperbound. WMO No. 853. World Meteorological Organization. ISBN 9263-10853-6. (NP-6/97)

The World's Water: Is There Enough? 1997. 22 pp. \$20.00. Paperbound. WMO No. 857. World Meteorological Organization. ISBN 92-63-10857-9. (NP-9/97)

\section{Instrumentation}

The Advanced Very High Resolution Radiometer. Arthur P. Cracknell. 1997. 534 pp. \$115.00. Hardbound. Taylor \& Francis. ISBN 0-7484-0209-8. (NP-9/97; R-12/97)
Guide to Meteorological Instruments and Methods of Observation. Sixth Edition. 1996. 200 pp. $\$ 155.00$. Spiralbound. WMO No. 8. World Meteorological Organization. ISBN 92-6316008-2. (NP-9/97)

Reliable Spectroradiometry. Henry J. Kostkowski. 1997. 609 pp. $\$ 200.00$. Clothbound. Spectroradiometry Consulting. ISBN 0-9657713-0-X. (NP-9/97; R-12) 97)

Remote Sensing Calibration Systems: An Introduction. H. S. Chen. 1996. 238 pp. $\$ 64.00$. Clothbound. A. Deepak Publishing. ISBN 0-937194-38-7. (NP-7/97)

$K-12$

BoxTopics: Storms and Weather Forecasting. 1997. Educational Activity Kit. \$34.95. Briarpatch. (NP-8/97; R-11/ 97)

Hazy Skies: Weather and the Environment. Jonathan D. W. Kahl. 1998. 64 pp. \$15.95. Hardbound. Lerner Publications. ISBN 0-8225-2530-5. (NP4/98)

Hurricanes. D. M. Souza. 1996. 48 pp. $\$ 14.95$. Hardbound. Carolrhoda Books. ISBN 0-87614-861-5. (R-6/97)

Our Endangered Planet: Atmosphere. Mary Hoff and Mary M. Rodgers. 1995. 72 pp. \$21.50. Hardbound. Carolrhoda Books. ISBN 0-8225-2509-7. (R-5/97)

Weather Chronicles. Chip Taylor. 1997. 30 min. \$29.95. Videotape. Chip Taylor Communications. (NP-12/97; R-3/98)

Weather Watch: Forecasting the Weather. Jonathan D. W. Kahl. 1996. 72 pp. \$14.95. Hardbound. Lerner Publications. ISBN 0-8225-2529-1. (R-5/97)

\section{Long-Range Transport}

The Impact of Desert Dust across the Mediterranean. Stefano Guerzoni and Roy Chester, Eds. 1996. 404 pp. \$180.00. Hardbound. Kluwer Academic Publishers. ISBN 0-7923-4294-1. (NP-9/97; R-3/ 98) 


\section{Miscellaneous}

Annual Report 1996. 1997. 61 pp. $\$ 27.00$. Paperbound. WMO No. 859 . World Meteorological Organization. ISBN 92-63-10859-5. (NP-9/97)

The Earth and the Cosmos: The Legacy of Hans Ertel. Wilfried Schröder and Hans-Jürgen Treder, Eds. 1997. 382 pp. $\$ 20.00$. Paperbound. Science Edition. ISSN 0179-5658. (NP-1/98)

Encyclopedia of Climate and Weather. Vols. 1 \& 2. Stephen H. Schneider, Ed. 1996. 929 pp. \$195.00. Clothbound. Oxford University Press. ISBN 0-19-5094859. $(R-5 / 97)$

Noctilucent Clouds: Leuchtende Nachtwolken (Theoretical Concepts and Observational Implications). Wilfried Schröder. 1998. 330 pp. $\$ 20.00$. Paperbound. Science Edition. ISSN 01795658. (NP-3/98)

Organizing Scientific Meetings. August Epple. 1996. 184 pp. \$14.95. Paperbound. Cambridge University Press. ISBN 0-52158919-3. (NP-8/97)

\section{Modeling}

Air Pollution Modeling and Its Application XI. Sven-Erik Gryning and Francis A. Schiermeier. 1996. 709 pp. $\$ 159.50$. Hardbound. Plenum Publishing. ISBN 0-306-45381-9. (NP-7/97)

Air Pollution V: Modelling, Monitoring and Management. H. Power, T. Tirabassi, and C. A. Brebbia, Eds. 1997. 1036 pp. $\$ 395.00$. Hardbound. Computational Mechanics. ISBN 1-853-12473-7. (NP-2/ 98)

Computer Modelling of Seas and Coastal Regions III. J. R. Acinas and C. A. Brebbia, Eds. 1997. 350 pp. \$150.00. Hardbound. Computational Mechanics. ISBN 1-85312499-0. (NP-1/98)

Computer Models of Watershed Hydrology. Vijay P. Singh, Ed. 1995. 1144 pp. \$95.00. Hardbound. Water Resources Publications. ISBN 0-918334-91-8. (NP8/97; R-11/97)
Distributed Hydrological Modelling. Michael B. Abbott and Jens Christian Refsgaard, Eds. 1996. 321 pp. \$158.00. Hardbound. Kluwer Academic Publishers. ISBN 0-7923-4042-6. (NP-6/97; R-2) 98)

Guidelines for Use of Vapor Cloud Dispersion Models. Second Edition. Steven R. Hanna and Peter J. Drivas. 1997. 271 pp. \$140.00. Hardbound. American Institute of Chemical Engineers. ISBN 08169-0702-1. (NP-7/97; R-2/98)

Mathematical Techniques for Water Waves. B. N. Mandal, Ed. 1997. 375 pp. $\$ 129.00$. Hardbound. Computational Mechanics. ISBN 1-853-12413-3. (NP-10/ 97)

Numerical Simulations in the Environmental and Earth Sciences. Fernando García et al., Eds. 1997. 283 pp. $\$ 69.95$. Hardbound. Cambridge University Press. ISBN 0-52 1-58047-1. (NP-3/98)

Singular Spectrum Analysis: A New Tool in Time Series Analysis. James B. Elsner and Anastasios A. Tsonis. 1996. 164 pp. $\$ 49.50$. Hardbound. Plenum Publishing. ISBN 0-306-45472-6. (NP-6/97; R-10) 97)

Turbulence, Coherent Structures, Dynamical Systems and Symmetry. Philip Holmes, John L. Lumley, and Gal Berkooz. 1996. 420 pp. \$69.95. Clothbound. Cambridge University Press. ISBN 0-521-55142-0. (R-12/97)

Windows on Meteorology: Australian Perspective. Erik K. Webb, Ed. 1997. 342 pp. \$49.95. Paperbound. CSIRO Publishing. ISBN 0-642-06038-3. (NP-2/98)

\section{Numerical Weather Prediction}

Everybody Talks About It. A.-Wiin Nielsen. 1997. 96 pp. \$-unavailable. Paperbound. The Royal Danish Academy of Sciences and Letters. ISBN 87-7304-288-9. (NP-2/98) 
Ocean-Atmosphere Interaction

The Air-Sea Interface: Radio and Acoustic Sensing, Turbulence and Wave Dynamics. M. A. Donelan, W. $H$. Hui, and W. J. Plant, Eds. 1996. 789 pp. $\$ 100.00$. Clothbound. RSMAS/University of Miami. ISBN 0-930050-00-2. (NP-12) 97; $\mathbf{R - 2 / 9 8 )}$

Air-Water Gas Transfer. B. Jähne and E. C. Monahan, Eds. 1995. 900 pp. \$60.00. Hardbound. Aeon Verlag \& Studio. ISBN 3-9804429-0-X. (R-5/97)

Atlas of the Oceans: Wind and Wave Climate. Ian R. Young and Greg J. Holland. 1996. 241 pp. \$960.00. Hardbound and CD-ROM. Elsevier Science. ISBN 0-08-042435-X. (R-7/97)

Nonlinear Ocean Waves. W. Perrie, Ed. 1997. 258 pp. \$135.00. Hardbound. Computational Mechanics. ISBN 1-85312414-1. (NP-3/98)

The Oceans and Climate. Grant R. Bigg 1996. 266 pp. \$27.95. Paperbound. Cambridge University Press. ISBN 0-52158268-7. (NP-5/97)

The Sea Surface and Global Change. Peter S. Liss and Robert A. Duce, Eds. 1996. 496 pp. \$59.95. Hardbound. Cambridge University Press. ISBN 0-521-56273-2. (NP6/97)

\section{Oceanography}

The Air-Sea Interface: Radio and Acoustic Sensing, Turbulence and Wave Dynamics. M. A. Donelan, W. H. Hui, and W. J. Plant, Eds. 1996. 789 pp. $\$ 100.00$. Clothbound. RSMAS/University of Miami. ISBN 0-930050-00-2. (NP-12) 97; $\mathbf{R}-\mathbf{2 / 9 8}$

Air-Water Gas Transfer. B. Jähne and E. C. Monahan, Eds. 1995. 900 pp. $\$ 60.00$. Hardbound. Aeon Verlag \& Studio. ISBN 3-9804429-0-X. (R-5/97)

Computer Modelling of Seas and Coastal Regions III. J. R. Acinas and C. A. Brebbia, Eds. 1997. 350 pp. \$150.00. Hardbound. Computational Mechanics. ISBN 1-85312499-0. (NP-1/98)
Encyclopedia of Climate and Weather. Vols. 1 \& 2. Stephen H. Schneider, Ed. 1996. 929 pp. \$195.00. Clothbound. Oxford University Press. ISBN 0-19-5094859. (R-5/97)

Mathematical Techniques for Water Waves. B. N. Mandal, Ed. 1997. 375 pp. $\$ 129.00$. Hardbound. Computational Mechanics. ISBN 1-853-12413-3. (NP-10/ 97)

The Ocean Circulation Inverse Problem. Carl Wunsch. 1996. 442 pp. \$54.95. Hardbound. Cambridge University Press. ISBN 0-521-48090-6. (R-4/98)

Ocean Circulation Theory. Joseph Pedlosky. 1996. 464 pp. \$89.95. Hardbound. Springer-Verlag. ISBN 3-540-60489-8. (R1/98)

\section{Paleoclimatology}

European River Activity and Climatic Change during the Lateglacial and Early Holocene. Burkhard Frenzel, Ed. 1995. 226 pp. \$46.50. Paperbound. Gustav Fischer Verlag. ISBN 3-437-30806-8. (R5/97)

Global Continental Palaeohydrology. K. J. Gregory, L. Starkel, and V. R. Baker, Eds. 1996. 400 pp. \$132.00. Clothbound. John Wiley \& Sons. ISBN 0-471-95420-9. (NP5/97; R-4/98)

The Limnology, Climatology and Paleoclimatology of the East African Lakes. Thomas C. Johnson and Eric O. Odada, Eds. 1996. 664 pp. \$140.00. Hardbound. Gordon and Breach Publishers. ISBN 2-88449-234-8. (R-5/ 97)

Problems of Stable Isotopes in TreeRings, Lake Sediments and Peat-Bogs as Climatic Evidence for the Holocene. Burkhard Frenzel and Bernhard Stauffer, Eds. 1995. 189 pp. \$47.50. Paperbound. Gustav Fischer Verlag. ISBN 3-437-30817-3. (R5/97) 


\section{Planetary/Space Research}

Introduction to Geomagnetic Fields. Wallace H. Campbell. 1997. 290 pp. $\$ 69.95$. Hardbound. Cambridge University Press. ISBN 0-521-57193-6. (NP-2/98)

\section{Policy}

Does the Weather Really Matter? The Social Implications of Climate Change. William James Burroughs. 1997. 224 pp. \$24.95. Hardbound. Cambridge University Press. ISBN 0-521-56126-4. (NP-12/97; R-3/98)

Earth Under Siege. Richard P. Turco. 1997. 527 pp. \$50.00. Hardbound. Oxford University Press. ISBN 0-19-507286-3. (NP12/97; R-4/98)

Economic Value of Weather and Climate Forecasts. Richard W. Katz and Allan H. Murphy, Eds. 1997. 237 pp. $\$ 49.95$. Hardbound. Cambridge University Press. ISBN 0-52 1-43420-3. (NP-12/97; R-3/98)

The Endangered Atmosphere: Preserving a Global Commons. Marvin S. Soroos. 1997. 360 pp. \$39.95. Clothbound. University of South Carolina Press. ISBN 1-57003-160-6. (NP-12/97; R-1/98)

Global Warming: The Complete Briefing. J. Houghton. 1997. 251 pp. \$22.95. Paperbound. Cambridge University Press. ISBN 0-52 1-62932-2. (NP-4/98)

Global Warming: The Truth behind the Myth. Michael L. Parsons. 1995. 260 pp. $\$ 27.95$. Hardbound. Plenum Publishing. ISBN 0-306-45083-6. (NP-5/97; R-9/ 97)

The Heat Is On: The High Stakes Battle over Earth's Threatened Climate. Ross Gelbspan. 1997. 278 pp. \$23.00. Hardbound. Addison Wesley Longman. ISBN 0-201-13295-8. (R- 10/97)

Laboratory Earth: The Planetary Gamble We Can't Afford to Lose. Stephen H. Schneider. 1997. 174 pp. $\$ 20.00$. Hardbound. BasicBooks. ISBN 0-465-072798. (NP-5/97; R-7/97)
Policy Making Global Change: Policy Making in an Era of Global Environmental Change. R. E. Munn, J. W. M. la Rivière, and N. van Lookeren Campagne, Eds. 1996. 225 pp. $\$ 49.50$. Hardbound. Kluwer Academic Publishers. ISBN 0-7923-3872-3. (NP-5/97; R-6) 97)

The World's Water: Is There Enough? 1997. 22 pp. $\$ 20.00$. Paperbound. WMO No. 857. World Meteorological Organization. ISBN 92-63-10857-9. (NP-9/97)

\section{Popular}

BoxTopics: Storms and Weather Forecasting. 1997. Educational Activity Kit. \$34.95. Briarpatch. (NP-8/97; R-11) 97)

Florida Hurricanes and Tropical Storms. John M. Williams and Iver W. Duedall. 1997.148 pp. \$12.95. Paperbound. University Press of Florida. ISBN 0-8130-1515-4. (NP-5/97; R-1/ 98)

Global Warming: The Complete Briefing. J. Houghton. 1997. 251 pp. \$22.95. Paperbound. Cambridge University Press. ISBN 0-52 1-62932-2. (NP-4/98)

Global Warming: The Truth behind the Myth. Michael L. Parsons. 1995. 260 pp. $\$ 27.95$. Hardbound. Plenum Publishing. ISBN 0-306-45083-6. (NP-5/97; R-9) 97)

The Great Cyclone at St. Louis and East St. Louis, May 27, 1896. Julian Curzon, Ed. 1997.429 pp. \$12.95. Paperbound. Southern Illinois University Press. ISBN 0-8093-2124-6. (NP-9/97)

The Handy Weather Answer Book. Walter A. Lyons. 1997. 397 pp. \$16.95. Paperbound. Visible Ink Press. ISBN 0-78761034-8. (NP-12/97)

The Heat Is On: The High Stakes Battle over Earth's Threatened Climate. Ross Gelbspan. 1997. 278 pp. \$23.00. Hardbound. Addison Wesley Longman. ISBN 0-201-13295-8. (R-10/97) 
Laboratory Earth: The Planetary Gamble We Can't Afford to Lose. Stephen H. Schneider. 1997. 174 pp. \$20.00. Hardbound. BasicBooks. ISBN 0-465-072798. (NP-5/97; R-7/97)

The Perfect Storm. Sebastian Junger. 1997. 227 pp. \$23.95. Hardbound. W. W. Norton \& Company. ISBN 0-393-04016-X. (NP-12/97)

Perils of a Restless Planet: Scientific Perspectives on Natural Disasters. Ernest Zebrowski Jr. 1997. 306 pp. \$24.95. Hardbound. Cambridge University Press. ISBN 0-521-57374-2. (NP-12/97)

Restless Earth: Disasters of Nature. $\mathrm{H}$. J. de Blij et al. 1997.288 pp. $\$ 35.00$. Clothbound. National Geographic Society. ISBN 0-7922-7026-6. (NP-12/97)

Skywonkie. Adrian Gordon. 1996. 265 pp. $\$ 7.99$. Paperbound. Minerva Press. ISBN 1-85863-931-X. (NP-5/97)

Thunder in the Heartland. A Chronicle of Outstanding Weather Events in Ohio. Thomas W. Schmidlin and Jeanne Appelhans Schmidlin. 1996. 373 pp. \$45.00. Clothbound. Kent State University Press. ISBN 087338-549-7. (R- 12/97)

Under the Whirlwind. Arjen and Jerrine Verkaik. 1997. 224 pp. \$25.00. Paperbound. Whirlwind Books. ISBN 09681537-0-4. (NP-9/97; R-1/98)

Weather Chronicles. Chip Taylor. 1997. 30 min. $\$ 29.95$. Videotape. Chip Taylor Communications. (NP-12/97; R-3/98)

Radar

Applications of Weather Radar Systems. Second Edition. Christopher G. Collier. 1996. 390 pp. $\$ 70.00$. Hardbound. John Wiley \& Sons. ISBN 0-471-96013-6. (NP5/97; R-9/97)

Images in Weather Forecasting: A Practical Guide for Interpreting Satellite and Radar Imagery. M. J. Bader et al., Eds. 1995. 499 pp. $\$ 135.00$. Hardbound. Cambridge University Press. ISBN 0-52 1-45 111 1-6. (R-8/97)

\section{Remote Sensing}

The Advanced Very High Resolution Radiometer. Arthur P. Cracknell. 1997. 534 pp. \$115.00. Hardbound. Taylor \& Francis. ISBN 0-7484-0209-8. (NP-9/97; R-12/97)

Applications of Weather Radar Systems. Second Edition. Christopher G. Collier. 1996. 390 pp. $\$ 70.00$. Hardbound. John Wiley \& Sons. ISBN 0471-96013-6. (NP-5/97; R-9/97)

Earth from Above: Using Color-Coded Satellite Images to Examine the Global Environment. Claire L. Parkinson. 1997. 175 pp. \$24.00. Paperbound. University Science Books. ISBN 0-935702-415. (NP-10/97; R-11/97)

Images in Weather Forecasting: A Practical Guide for Interpreting Satellite and Radar Imagery. M. J. Bader et al., Eds. 1995. 499 pp. \$135.00. Hardbound. Cambridge University Press. ISBN 0-521-4511 1 -6. (R-8/97)

Integration of Geographic Information Systems and Remote Sensing. Jeffrey L. Star, John E. Estes, and Kenneth C. McGwire, Eds. 1997. 225 pp. \$49.95. Hardbound. Cambridge University Press. ISBN 0-52144032-7. (NP-6/97)

Introduction to the Mathematics of Inversion in Remote Sensing and Indirect Measurements. S. Twomey. 1996. 243 pp. \$9.95. Paperbound. Dover Publications. ISBN 0-486-69451-8. (NP-9/ 97)

Reliable Spectroradiometry. Henry J. Kostkowski. 1997. 609 pp. $\$ 200.00$. Clothbound. Spectroradiometry Consulting. ISBN 0-9657713-0-X. (NP-9/97; R-12/ 97)

Remote Sensing Calibration Systems: An Introduction. H. S. Chen. 1996. 238 pp. $\$ 64.00$. Clothbound. A. Deepak Publishing. ISBN 0-937194-38-7. (NP-7/97) 


\section{Satellite Meteorology}

Images in Weather Forecasting: A Practical Guide for Interpreting Satellite and Radar Imagery. M. J. Bader et al., Eds. 1995. 499 pp. \$135.00. Hardbound. Cambridge University Press. ISBN 0-521-451 1 1-6. (R-8/97)

Integration of Geographic Information Systems and Remote Sensing. Jeffrey L. Star, John E. Estes, and Kenneth C. McGwire, Eds. 1997. 225 pp. \$49.95. Hardbound. Cambridge University Press. ISBN 0-52 1-44032-7. (NP-6/97)

Introduction to the Mathematics of Inversion in Remote Sensing and Indirect Measurements. S. Twomey. 1996. 243 pp. \$9.95. Paperbound. Dover Publications. ISBN 0-486-69451-8. (NP9/97)

An Introduction to Satellite Image Interpretation. Eric D. Conway and the Maryland Space Grant Consortium. 1997. 242 pp. \$29.95. Paperback (includes CDROM). Johns Hopkins University Press. ISBN O8018-5572-2. (NP-2/98)

\section{Severe Weather}

Florida Hurricanes and Tropical Storms. John M. Williams and Iver W. Duedall. 1997. 148 pp. \$12.95. Paperbound. University Press of Florida. ISBN 0-8130-1515-4. (NP5/97; R-1/98)

The Great Cyclone at St. Louis and East St. Louis, May 27, 1896 . Julian Curzon, Ed. 1997. 429 pp. \$12.95. Paperbound. Southern Illinois University Press. ISBN 0-8093-2124-6. (NP-9/97)

Hurricanes. D. M. Souza. 1996. 48 pp. $\$ 14.95$. Hardbound. Carolrhoda Books. ISBN 0-87614-861-5. (R-6/97)

Hydrology of Disasters. Vijay P. Singh. 1996. 456 pp. \$215.00. Hardbound. Kluwer Academic Publishers. ISBN 0-7923-4092-2. (NP-5/97; R-11/97)
Perils of a Restless Planet: Scientific Perspectives on Natural Disasters. Ernest Zebrowski Jr. 1997. 306 pp. \$24.95. Hardbound. Cambridge University Press. ISBN 0-521-57374-2. (NP-12/97)

Restless Earth: Disasters of Nature. H. J. de Blij et al. 1997. 288 pp. \$35.00. Clothbound. National Geographic Society. ISBN 0-7922-7026-6. ( '-12/97)

Thunder in the Heartland. A Chronicle of Outstanding Weather Events in Ohio. Thomas W. Schmidlin and Jeanne Appelhans Schmidlin. 1996. 373 pp. \$45.00. Clothbound. Kent State University Press. ISBN O87338-549-7. (R-12/97)

Under the Whirlwind. Arjen and Jerrine Verkaik. 1997. 224 pp. \$25.00. Paperbound. Whirlwind Books. ISBN 09681537-0-4. (NP-9/97; R-1/98)

\section{Statistical Analysis}

Applications of Time Series Analysis in Astronomy and Meteorology. T. Subba Rao, M. B. Priestly, and O. Lessi, Eds. 1997. 465 pp. \$1 19.95. Hardbound. Chapman \& Hall. ISBN 0-4 $12-63800-2$. (NP-1/98)

Computational Statistics in Climatology. Ilya Polyak. 1996. 358 pp. \$65.00. Clothbound. Oxford University Press. ISBN 0-19-509999-0. (R-5/97)

Introduction to Geostatistics: Applications in Hydrogeology. $P . \mathrm{K}$. Kitanidis. 1997. 249 pp. \$29.95. Paperbound. Cambridge University Press. ISBN 0-521-58747-6. (NP-1/98)

Regional Frequency Analysis. J. R. M. Hosking and J. R. Wallis. 1997. 224 pp. $\$ 69.95$. Hardbound. Cambridge University Press. ISBN 0-52 1-43045-3. (NP-1/98)

\section{Synoptic Meteorology}

Earth from Above: Using Color-Coded Satellite Images to Examine the Global Environment. Claire L. Parkinson. 1997. 175 pp. \$24.00. Paperbound. University Science Books. ISBN 0-935702-415. (NP-10/97; R-11/97) 
Gravity Currents in the Environment and the Laboratory. Second Edition. John E. Simpson. 1997. 244 pp. \$74.95. Hardbound. Cambridge University Press. ISBN 0-521-56109-4. (NP-9/97)

Gravity Waves in Water in Finite Depth. J. N. Hunt, Ed. 1997.300 pp. \$129.00. Hardbound. Computational Mechanics. ISBN 1-85312-351-X. (NP-10/97)

\section{Textbooks}

Air Quality. Third Edition. Thad Godish. 1997. 448 pp. \$64.95. Hardbound. CRC Press. ISBN 1-56670-231-3. (NP-1/98)

Applications of Weather Radar Systems. Second Edition. Christopher G. Collier. 1996. 390 pp. $\$ 70.00$. Hardbound. John Wiley \& Sons. ISBN 0-471-96013-6. (NP5/97; R-9/97)

Chemistry of the Environment. Thomas G. Spiro and William M. Stigliani. 1996. 356 pp. \$59.50. Hardbound. Prentice Hall. ISBN 0-02-415261-7. (NP-5/97; R-9) 97)

Dynamic Meteorology: A Basic Course. A. Gorden et al. 1998. 325 pp. \$34.95. Paperbound. John Wiley \& Sons. ISBN 0-340-595035. (NP-4/98)

Environmental Oceanography. Second Edition. Tom Beer. 1997. 400 pp. \$79.95. Hardbound. CRC Press. ISBN 0-8493-8425. 7. (NP-5/97)

Introduction to Geostatistics: Applications in Hydrogeology. P. K. Kitanidis. 1997. 249 pp. \$29.95. Paperbound. Cambridge University Press. ISBN 0-521-58747-6. (NP-1/98)

Meteorology. Eric W. Danielson, James Levin, and Elliot Abrams. 1998. 462 pp. \$62.50. Paperbound. McGraw Hill Companies. ISBN 0-697-2171 1-6. (NP-2/98)

Meteorology: The Atmosphere and the Science of Weather. Fifth Edition. Joseph M. Moran and Michael D. Morgan. 1997.530 pp. \$60.00. Hardbound. Prentice Hall. ISBN 0-13-266701-0. (NP-5/97)

Principles of Atmospheric Physics and Chemistry. Richard Goody. 1995. 324 pp. \$45.00. Hardbound. Oxford University Press. ISBN 0-19-509362-3. (R-5/97)

Simulation and Modeling of Turbulent Flows. Thomas B. Gatski, M. Yousuff Hussaini, and John L. Lumley, Eds. 1996. 314 pp. \$39.95. Hardbound. Oxford University Press. ISBN 0-19-510643-1. (NP-5/97; R-8/97)

Weather Watch: Forecasting the Weather. Jonathan D. W. Kahl. 1996. 72 pp. \$14.95. Hardbound. Lerner Publications. ISBN 0-8225-2529-1. (R-5/97)

A World of Weather: Fundamentals of Meteorology. Second Edition. Jon $M$. Nese and Lee M. Grenci. 1998. 539 pp. $\$ 52.95$. Paperbound. Kendall/Hunt Publishing. ISBN 0-7872-3731-0. (NP-1/ 98)

\section{Tropical Meteorology}

El Niño Southern Oscillation and Climatic Variability. Rob Allan, Janette Lindesay, and David Parker. 1996. 416 pp. $\$ 1$ 10.00. Hardbound and CD-ROM. CSIRO Publishing. ISBN 0-643-05803-6. (NP-5/ 97; $\mathbf{R}-\mathbf{7 / 9 7 )}$

Florida Hurricanes and Tropical Storms. John M. Williams and Iver W. Duedall. 1997. 148 pp. \$12.95. Paperbound. University Press of Florida. ISBN 0-8130-1515-4. (NP5/97; R-1/98)

Hurricanes. D. M. Souza. 1996. 48 pp. $\$ 14.95$. Hardbound. Carolrhoda Books. ISBN 0-87614-861-5. (R-6/97)

\section{Upper Atmosphere}

Physics of the Upper Polar Atmosphere. Asgeir Brekke. 1997. 491 pp. \$44.95. Hardbound. John Wiley \& Sons. ISBN 0-47196018-7. (NP-5/97; R-2/98)

The Upper Atmosphere: Data Analysis and Interpretation. W. Dieminger, G. K. Hartmann, and R. Leitinger, Eds. 1995. 1032 pp. \$394.00. Hardbound. Springer-Verlag. ISBN 3-540-57562-6. (R-9/97) 


\section{book reviews}

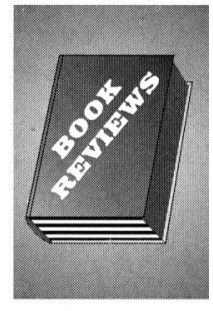

Antarctic Meteorology and Climatology. Cambridge Atmospheric and Space Science Series. J. C. King and J. Turner. 1997. 409 pp. $\$ 90.00$. Hardbound. Cambridge University Press. ISBN 0-52146560-5.

In the 14 years since the late Werner Schwerdtfeger published his scholarly treatise on Antarctic meteorology and climatology (Schwerdtfeger 1984), there have been a number of important developments. On the observational side, automatic weather stations (AWS) under Charles Stearns at the University of Wisconsin-Madison have matured into a platform capable of reliably operating in the full range of conditions found in Antarctica: from the coldest recorded temperature on earth at Vostok of $-89^{\circ} \mathrm{C}$ to the maritime conditions of offshore islands. Satellite remote sensing is steadily gaining in importance as an effective strategy to deal with the large gaps between observational sites, particularly as more quantitative measures are obtained. Numerical modeling is rapidly becoming an important tool to illuminate the governing processes and to interpolate in a physically consistent manner between the sparse observations. In view of these rapid and dramatic developments, it is appropriate to review the progress in Antarctic weather and climate since 1984. King and Turner have succeeded admirably in their ambitious goal to survey the state of the art.

The general meteorological reader will find much material of interest. Chapter 2 on observations and instrumentation should be singled out as it gives a modern synthesis of the sources of Antarctic observations, their limitations, and where the data can be obtained. Naturally this information will rapidly become dated, but it does directly address one of the main limitations preventing broader participation in Antarctic meteorological research-namely, where does one get data and how much can they be trusted?

(C) 1998 American Meteorological Society
The text is liberally sprinkled with NOAA satellite images collected at the British station at Rothera in the Antarctic Peninsula and well illustrates the importance and power of this data source.

Chapter 3 on physical climatology is a generally strong contribution. It provides good coverage of the surface radiation budget, temperature characteristics at the surface and in the free atmosphere, clouds and precipitation, and conditions in the Southern Ocean. The important circulation section on pressure, geopotential height, and wind is unfortunately cursory and incomplete. The description of the winds at the surface and in the free atmosphere needs substantial enhancement. It is also regrettable that a number of radiation figures contain some faint, barely readable curves.

Chapter 4 on the large-scale circulation of the Antarctic atmosphere approaches the topic by outlining the atmospheric budgets of heat, vorticity, and moisture. The heat budget primarily recounts the pioneering contribution of Nakamura and Oort (1988). The vorticity discussion performs an important service by emphasizing the coupling between the near-surface katabatic winds and the circulation of the free atmosphere. This starts to build the case that the Antarctic plays an important role in the globally coupled atmospheric circulation. The atmospheric moisture budget draws heavily on the contribution of radiosonde-based studies of the first author and predates the skillful and rapidly developing contributions being made by diagnoses of atmospheric numerical analyses. The chapter concludes with an incomplete and dated discussion of the depiction of Antarctic atmospheric processes by global climate models. It is disappointing that the authors did not have access to results from the Atmospheric Model Intercomparison Project to provide a more comprehensive and modern synthesis.

The chapter on synoptic-scale weather systems and fronts places the processes over Antarctica into the context of being on the poleward periphery of the Southern Ocean. Satellite imagery is used effectively to illustrate the characteristics of oceanic cyclones near Antarctica. Results from objective evaluation of 
atmospheric numerical analyses (after Jones and Simmonds 1993) are used to depict the climatological behavior of cyclogenesis, cyclone tracks, and cyclosis. The behavior of anticyclones is also described. Analysis over the elevated Antarctic continent is described with appropriate emphasis placed on Phillpot's (1991) technique for using observations from high elevation AWSs to infer the 500-hPa geopotential height with reasonable accuracy. There is a useful section on operational weather forecasting for Antarctica. The only drawback to this chapter is once again the figures: required stippling is absent from some figures (e.g., Fig. 5.28), fronts are present in many figures but are not clearly identified, there are quite a number of unexplained figure symbols, and finally some figures are too small to be clearly readable (Figs. 5.46-5.48).

Chapter 6, on mesoscale systems and processes, deals with aspects of katabatic and barrier winds. It contains a nice section on internal gravity waves that is mostly based on British work, discusses turbulent heat and momentum fluxes in the very stable Antarctic boundary layer, presents introductory material on blowing snow, and concludes with a long section on mesoscale cyclones, which have been a particular interest of the second author. Mesoscale cyclones are attracting more attention as it is now clear that the coastal areas of the continent are not solely regions of cyclonic dissipation, but are very cyclogenetically active, particularly on the mesoscale. These features are frequently the greatest weather constraint on operational activities. Continuing problems with the figures are illustrated by Figs. 6.34 and 6.35 being attributed to the wrong research paper. More recent and advanced material on Antarctic mesoscale cyclones is provided by Carleton (1996a,b).

The book concludes with a strong chapter on climate variability and change, delves into temperature and precipitation variations in the recent past, and the teleconnections with the El Niño-Southern Oscillation (ENSO) phenomenon, and wraps up with a summary of the simulated impact of "global warming" on Antarctica. The ENSO discussion is rapidly becom- ing dated as research is quickly advancing on this topic, and much more can be expected as a result of the major EL Niño event in 1997-98.

Overall, King and Turner have produced a nice update on Antarctic meteorology and climatology with a notable effort being made to place Antarctica in the broader scale context. Particularly strong aspects are the liberal use of satellite imagery for illustration and the extensive discussion of available data and data sources. The figures are a weakness of the book, as noted repeatedly above. A personal preference is the desirability of describing the surface wind regime of Antarctica in a more integrated fashion as it is such a dominant forcing mechanism in these latitudes. The book is well produced and sturdy. It deserves to be on the shelves of both the serious student of the Antarctic atmosphere as well as the more general reader who will find that many parts are quite accessible. It should be part of all good science libraries.-David H. Bromwich.

David H. Bromwich is a research meteorologist with the Byrd Polar Research Center of the Ohio State University in Columbus. He specializes in the meteorology and climatology of both polar regions and has contributed to many of the topics discussed by King and Turner.

\section{References}

Carleton, A. M., Ed., 1996a: Cold air mesocyclones in the Arctic and Antarctic, I. Global Atmos. Ocean Sys., 4, 1-361.

- 1996b: Cold air mesocyclones in the Arctic and Antarctic, II. Global Atmos. Ocean Sys., 5, 1-97.

Jones, D. A., and I. Simmonds, 1993: A climatology of Southern Hemisphere extratropical cyclones. Climate Dyn., 9, 131-145.

Nakamura, N., and A. H. Oort, 1988: Atmospheric heat budgets of the polar regions. J. Geophys. Res., 93, 9510-9524.

Phillpot, H. R., 1991: The derivation of $500 \mathrm{hPa}$ height from automatic weather station observations in the Antarctic continental interior. Aust. Meteor. Mag., 39, 79-86.

Schwerdtfeger, W., 1984: Weather and Climate of the Antarctic. Elsevier, $261 \mathrm{pp}$. 


\section{Understanding Environmental Pollution}

\section{Marquita K. Hill}

This lucidly-written and thorough approach to comprehending pollution issues systematically addresses issues from global stratospheric ozone depletion to personal pollution in the home.

\begin{tabular}{|c|c|c|}
\hline 1997 & $340 p$ & $\begin{array}{l}56210-4 \\
56680-0\end{array}$ \\
\hline
\end{tabular}

\section{The Earth's Plasmasphere \\ J.F. Lemaire and K.I. Gringauz}

This is the first monograph to describe the historical development of ideas concerning the plasmasphere by the pioneering researchers themselves. The monograph brings our picture of the plasmasphere up to date by presenting experimental and observational results of the past three decades, and mathematical and physical theories proposed to explain its formation.

Cambridge Atmospheric and Space Science Series

$1998 \quad 375$ pp. $43091-7$ Hardback $\$ 90.00$

\section{Climate Process and Change Edward Bryant}

This is the first major textbook to encompass the true complexity of climate change. While greenhouse warming dominates most of the literature, Bryant presents numerous reasons for the observed climate change of the past century. He argues that changes in climate, more dramatic than those of the past 150 years, have been a predominant aspect of the Earth's climate over the past two million years.

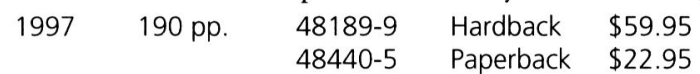

\section{Late Palaeozoic and Early Mesozoic Circum-Pacific Events and their Global Correlation}

J.M. Dickins, Yang Zunyi, Yin Hongfu,

S.G. Lucas, and S.K. Acharyya, Editors

In this volume, an international assemblage of geologists reveals a wide range of information about these events in the circum-Pacific region, as a conclusion to International Geological Correlation Programme Project 272. They explore the nature of the changes in the Late Paleozoic and Early Mesozoic, and suggest issues for future investigation through the study of paleontology, biostratigraphy, tectonics, magmatic and volcanic development, ore deposition, paleography and climate.

World and Regional Geology Series 11
1997
$255 \mathrm{pp}$.
47175-3 Hardback
$\$ 110.00$

\section{Mathematical Models in the Applied Sciences \\ A.C. Fowler}

This book presents a thorough grounding in the techniques of modeling, and proceeds to explore a range of classical and continuum models from an impressive array of disciplines, including biology, chemical engineering, fluid and solid mechanics, geophysics, medicine, and physics. It will provide a wealth of examples for students of mathematics, engineering, and the range of applied sciences.

Cambridge Texts in Applied Mathematics 17

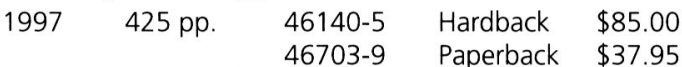

\section{Numerical Simulations in the Environmental and Earth Sciences} Proceedings of the Second UNAM-CRAY Supercomputing Conference

\section{Fernando García García, Gerardo Cisneros, Agustín Fernández-Eguiarte, and Román Álvarez, Editors}

The progress of numerical modeling in atmospheric, oceanic, and geophysical sciences was the topic of an international conference held by the National Autonomous University of Mexico. The review articles and research papers in this volume constitute a wide-ranging and up-to-date account of modeling environmental and earth processes through a variety of numerical simulations.

$1997 \quad 298$ pp. $\quad 58047-1 \quad$ Hardback $\$ 69.95$

\section{Now in paperback... \\ Topographic Effects in Stratified Flows \\ Peter G. Baines \\ "... a major achievement..." \\ -Larry Pratt,}

Bulletin of the American Meteorological Society

With an emphasis on both theory and experiment, this text describes the behavior of homogeneous and densitystratified fluids over and around topography. The topics include the flow of a homogeneous layer with a free surface - the prototype for conventional hydraulicsthe corresponding phenomena in two-layer flows, and a description of the properties of linear waves in stratified fluids in motion. The author applies the aforementioned properties to laboratory and numerical modeling of flow through real complex terrain.

Cambridge Monographs on Mechanics

$1997 \quad 498$ pp. 62923-3 Paperback $\$ 34.95$

\section{Available in bookstores or from}


Time and the River. Essays by Eminent Hydrologists. G. W. Kite, Ed. 1995. 362 pp. $\$ 58.00$. Hardbound. Water Resources Publications. ISBN 0-918334-97-7.

Hydrology is a relatively young science dealing with all aspects of the waters within and on the earth's crust and in the atmosphere, and their relation with living things. Although practiced for millennia as an essential part of human existence, it has its formal origin in the 1930s, when a group of hydraulic engineers decided to establish the International Association of Scientific Hydrology (IASH). Professor L. J. Tison of Belgium, secretary of the IASH for many years, confided once that the adjective scientific was added intentionally, to differentiate it from the "other hydrology," which, until the late 1800 s, was associated in literature with accounts of "taking the waters" in the various spas of Europe. Much progress has been made since then, and hydrology has become sufficiently respectable not to need the qualifier $s c i$ entific; but it is still developing, with some significant and many insignificant works being published. When out of this hothouse of esoteric publications comes a book with the simple title of Time and the River, one certainly does pause and take note; it seems that finally there is the promise of a book that people other than highly trained experts can understand and appreciate. The front cover of the book has a color photograph-supplied by the editor- of Antelope Canyon in Northern Arizona, showing in vivid yellows, oranges, and browns the wild beauty of the carved canyon walls. This is the place where, in August 1997, eleven unfortunate tourists, unaware or unbelieving of the sudden fury of flash floods and debris flows, were swept to their tragic deaths by the raging waters. T. S. Eliot's river, "the strong brown god," had again spoken.

The title and photo raise expectations that the essays would explore the history of man's interaction with the waters in the environment in a language accessible to the general public. Although the concern for the interaction is present in some of the essays, the popularization is absent; the address is to the professional hydrologist.

The contributions to this volume are: Introduction-G. W. Kite, Ed.; Capturing the Hydrological Cycle-J. C. Rodda; Hydrology in the Developing World-J. V. Sutcliffe; Hydrological Information and International Rivers-R. H. Clark; Statistics in Hydrology and Water Resources Management-V.
Yevjevich; Evaporation and Feedback Mechanisms in Hydrology - F. I. Morton; The Development of a Hydrological Model-TANK - M. Sugawara; Climatic Change, River Flows and Water Resources Development-G. Cavadias; Macro-Scale Hydrology-S. I. Solomon; and General Circulation Models (GCMs), Climatic Change, Scaling and Hydrology_-J. Nemec.

The selection of contributors is explained by the editor: "They are also scientists with whom I have been proud to work with over the last 25 years."

A common affliction of anthologies and teamtaught courses is that chapters tend to be uneven in length, style, and content; this is no different here. Kites introduces the theme of the book as trying to provide answers to questions such as, "Where are we in hydrology? What has been achieved in the last thirty or forty years? In which direction should we be moving?" In addition to his own summary, he gives an overview of the authors' experiences, accomplishments, and views. This is a lively chapter with astute observations on the state of the art in hydrology and clever quotations such as the one by E. J. Gumbel: "It seems that the rivers know the [extreme value] theory. It only remains to convince the engineer of the validity of this analysis."

Rodda and Clark give valuable and sober advice in their respective chapters. I confess, however, to some disappointment with Clark, not in the presentation, but in the selection of the topic. Clark is the godfather of hydrology in Canada. He was instrumental in setting up in 1957 the permanent Subcommittee of Hydrology and promoted hydrology in Canada when most of the water resources engineering community was entrenched in hydraulic and coastal engineering. I had hoped that he would be more conversational and tell us the inside story of the historic events and transformations that took place in Canada and elsewhere.

Sutcliffe and Morton stress the common sense approach to the real-world problems of hydrology. By means of well-chosen examples from the developing world, Sutcliffe shows that even in the absence of long hydrological records-desirable as they may be-it is possible to estimate solutions to regional water resources problems by judicious use of climatological data and rainfall-runoff relationships.

Morton's essay will probably ruffle some feathers in the hydrometeorological community. He justly argues that small-scale processes, such as the use of eddy correlation and Bowen ratio energy balance techniques, give only point values and are not amenable to routine measurement because of the high cost of 
instrumentation and the need for constant attendance by skilled personnel. Morton suggests that environmental research should "involve a study of natural systems as they actually exist after feedback mechanisms have modified, or even reversed, the effects of small-scale processes."

Yevjevich gives a staccato presentation of the historical contributions of scientists and engineers such as Hazen, Gumbel, Sudler, Hurst, Varlet, and others and discusses potential future problems and methods to solve them.

Sugawara gives a clear and detailed description of the historical development of his rainfall-runoff model TANK. The enthusiastic and single-minded exposition of the virtues of his model had me nearly convinced

\section{The enthusiastic and single-minded exposition of the virtues of his model had me nearly convinced that we had found the mother of all precipitation-runoff models...}

that we had found the mother of all precipitation-runoff models until I reminded myself that models are like comedies-they entertain and amuse us. Some successful models might provide sufficient information and insight to be a valuable tool in the hands of the cognoscenti.

In the light of the rapid technological advances in hydrometeorology, the last three essays are particularly topical. Cavadias discusses methods for detecting anthropogenic changes occurring over relatively short time periods; he concludes that considerable work will be necessary to arrive at satisfactory detection and modeling methodologies for studying the impact of climatic change on hydrologic series. While the flexibility of today's water resources management practices allow us to cope with the immediate impacts of climate change, the development of theoretical underpinnings will be necessary for adequate management practices.

Solomon gives a good overview of the nature, methodology, and problems of macroscale hydrology, with illustrations from projects in which he was involved. Although he acknowledges the difficulty of the undertakings, he is optimistic that remote sensing, backed by ground truth, will lead to acceptable and economic methods of data collection, especially from large and mostly inaccessible watersheds.

Nemec, in his succinct discussion of GCMs, has the philosophical outlook of the concerned scientist. He concedes that global change forced by human activity is real, but like Morton, worries that feedback forces are being ignored. He asks, "Can we be certain that the change we are witnessing is irreversible and caused by human activity?"

All of the essays reflect the professional experiences of the contributors and include ample references. Although the authors generally promote their own models and methodologies or those they are associated with, the philosophical outlooks are universally informative and challenging. I enjoyed this anthology, very likely because I essentially agreed with much of the presented material; others may not feel as comfortable. Academics have inherited the theological tradition of the medieval universities and tend to see and interpret the facts through the filter of their own dogmas; we feel smug when our beliefs are confirmed and bellicose when they are not. Whatever the point of view, this volume is a welcome addition to the hydrological literature; in particular, it could be used as a guide in discussion classes for graduate students of hydrology and hydrometeorology.-Simon Ince.

Simon Ince is a professor of hydrology and water resources and civil engineering at The University of Arizona, Tucson.
Agricultural Uses of Occult Precipitation. Andres N. Acosta Baladon. 1995. 146 pp. \$22.00. Paperbound. Agrometeorological Applications Associates.

The author defines occult precipitation as the atmospheric supply of water to soil or vegetation by means other than rainfall. Dew, fog, and low clouds all are forms of occult precipitation. The topic is rarely discussed in the meteorological literature but is of great historical interest, and perhaps of even greater practical interest in many regions of the world. Certain climatic and microclimatic conditions make occult precipitation an attractive alternative to other forms of water supply for agricultural purposes. In places such as the Canary Islands, Spain, Chili, Peru, 
and Oman, among others, exploitation of this form of water supply has been successfully demonstrated. The book provides a rather extensive historical review of the documented practices of using dew and low clouds for irrigation of crops.

The book covers three broad aspects of occult precipitation: the physical processes of dew, frost, and fog; their importance in agriculture, including adaptive abilities of certain vegetation to varied wateravailability conditions; and simple engineering techniques of occult water retrieval. In addition, the author discusses historical development of dew measurement instrumentation and methods of frost control. The book is illustrated with several color photographs that are helpful.

The quality of the book itself is unfortunately rather low. Material is not well organized, which results in frequent repetitions and lack of an overarching structure. The description of the physical processes of occult precipitation is often oversimplified and is certainly not adequate for study of the subject. Discussion of the relevant agricultural practices is too brief and sketchy to be of much practical help. Of the several sections, the engineering methods of fog and cloud water trapping are the most comprehensive. The technical quality of the graphics is very low.
The book almost certainly could not serve as a text in a rigorous program, nor is it exhaustive and technically accurate enough to serve as a serious reference. However, despite all flaws mentioned, I found the book interesting and inspirational. The author is certainly passionate about his subject, and the book combines knowledge from meteorology, climatology, agriculture, plant physiology, hydrology, and engineering, which makes it unique. Indeed, this technology transfer is the main aim of the volume, and it is successfully carried out. Considering the lack of generally accessible literature on the subject of occult precipitation, I would recommend the book, particularly to those who intend to practice meteorology, irrigation, and civil engineering in developing countries with limited water resources and conditions amenable to occurrence of occult precipitation.-Witold F. Krajewski.

Witold F. Krajewski is a professor of civil and environmental engineering at the University of Iowa and a research engineer at the Iowa Institute of Hydraulic Research. He conducts research on modeling, estimation, and prediction of precipitation using remote sensing techniques.
Remote Sensing of the Lower AtmosphereAn Introduction. Graeme L. Stephens. 1994. 523 pp. $\$ 65.00$. Hardbound. Oxford University Press. ISBN 0-19-508188-9.

This book is a useful contemporary text on the subject of atmospheric remote sensing. It provides a clear understanding of the interactions between radiation and the atmosphere, which result in measurable signatures that are exploited and used for remote sensing. Appealing to both the graduate student of atmospheric sciences and the professional meteorologist/ atmospheric scientist, principles are described in a manner that stimulates creativity and provides a broad understanding of the physical basis for contemporary atmospheric remote sensing.

The author, a world-class atmospheric scientist, has drawn material for this book from lecture notes compiled for courses on remote sensing and atmospheric radiation, which he teaches at Colorado State University. As a result, this book is written in a manner that makes it a useful course textbook. Of particular use to the student is the "Notes and Comments" section and the often mind-teasing problems at the end of each chapter. The instructors will find the "Class Projects" presented in an appendix helpful in formulating small class research problems as part of their course.

\section{...principles are described in a manner that stimulates creativity and provides a broad understanding of the physical basis for contemporary atmospheric remote sensing.}

I have chosen to use this book as a primary reference text for a course entitled "Atmospheric Technology," which I have taught at the University of Wisconsin-Madison (UW). Even though my emphasis is more equally weighted between the technology and the techniques of remote sensing, this book is an extremely useful text; it is unique in the availability of its content in a published format. This review is writ- 
ten from my experience with the use of this book for the "Atmospheric Technology" course taught to honors undergraduate and graduate students at UW.

The book starts by giving the reader a brief taste of the physical basis and practical problems associated with atmospheric remote sensing, including the mathematically ill-posed nature of inversion of the radiative transfer equation. A concise description of molecular and particulate composition is provided as a prelude to a discussion in later chapters of those properties that make them radiatively active. An abbreviated overview of satellite orbital mechanics sets the stage for discussion of the history of satellite remote sensing as a tool for operational meteorology and environmental research.

I found the presentation on electromagnetic radiation very useful in its mathematical content; the instructor can supplement this material with practical/ physical examples. In my course, however, I extend this material to include a derivation of the radiative transfer equation in two ways: one based purely on a numerical representation of the physical processes involved (i.e., emission, absorption, and scattering) and the other based on a mathematical integration of Schwarzschild's equation. Instead, Stephens chooses to delay the presentation of this fundamental relation, the radiative transfer equation, until later in the book when techniques for passive and active remote sensing are described.

I found Stephen's sections of the book on molecular absorption, optical properties, and particle scattering to be well organized and quite adequate for providing the reader with the fundamental physics associated with radiative transfer. The author's presentations of practical applications of the underlying physics within sections titled "Excursus" are extremely useful for understanding the complex processes involved.

Beyond the first half of the book, which is devoted to basic physics found in other texts on radiative transfer, the second half focuses on the explanation of contemporary remote sensing techniques. The sections on passive methods provide an adequate overview of the use of the microwave, infrared, and visible portions of the spectrum. Although a specialist in any of these areas might be disappointed, for the nonspecialist, and student, the treatment is at a level easily understood. I view the material presented to be basic, with the opportunity left for the instructor to enhance those areas of his or her own expertise and personal interest. Another enhancement left to the user of this book is a discussion of the improvement to be expected in passive remote sensing capability from emerging technologies and through the synergy of absorption and emission techniques when used over the entire useful range of the electromagnetic spectrum.

The final section of the book is devoted to active remote sensing. Modern radar methods are presented, including the use of Doppler systems for measuring wind profiles. An important deficiency, recognized by the author, is the exclusion of RAMAN Lidar used for ground-based profiling of atmospheric water vapor profiles. The RAMAN technique, which needs to be added by the instructor or acquired elsewhere by the reader, is now recognized as the best means for ground-based profiling of water vapor, a spatially structured and rapidly varying atmospheric constituent.

Finally, it is noted that if the text were to be written today it would probably be organized into sections dealing with the observation of a particular atmospheric constituent rather than according to a particular radiative process, wavelength region, sensing principle, or sensor platform. This is because no single remote sensing approach provides the accuracy and resolution desired for all atmospheric species of interest. It is now recognized that the synergism of both active and passive methodologies (based on absorption, emission, and scattering principles) is needed to improve the accuracy of our remote sensing products. Nevertheless, Remote Sensing of the Lower Atmosphere-An Introduction will remain a useful text and reference on the subject for the foreseeable future.-William L. Smith.

William L. Smith, chief of the Atmospheric Sciences Division at NASA Langley Research Center, is a professor of atmospheric science currently on leave from the Department of Atmospheric and Oceanic Sciences at the University of Wisconsin-Madison. 
Restless Earth: Disasters of Nafure. H. J. de Blii et al. 1997. 288 pp. $\$ 35.00$. Clothbound. Random House. ISBN 0-7922-7026-6.

Restless Earth consists of more than 100 pictures of violent or extreme disturbances of the earth's crust, the ocean, and the atmosphere, together with brief essays describing or commenting on the events illustrated. The text is addressed to a popular audience and is written in nontechnical language; however, the range is broad enough that even professional geophysicists are likely to find a few new and interesting facts and ideas. The quality and variety of the photographs qualify the book for display on coffee tables; this appraisal is supported also by its weight and size.

The foreword, contributed by H. J. Blij and R. S. Williams Jr., provides a succinct overview of the rest of the book. Under the title, "Our Living Planet," R. Lipkin presents 20 short discussions of a wide array of crustal movements, severe weather events, and features of climate. This chapter serves as an introduction to the following chapters. "Severe Storms" consists of 24 essays including historical accounts, vivid descriptions, and elementary expositions or explanations

"A very readable and clear book about some complex global environmental problems. I recommend the book highly." -Paul Crutzen, Bulletin of the American Meteorological Society

The Forgiving Air is an authoritative, up-to-date handbook on global change. Highlighting the interrelatedness of human activity and global change, Somerville humanizes the great environmental issues of our time - the hole in the ozone layer, the greenhouse effect, acid rain, and air pollution. of storm phenomena. This chapter was written by $\mathrm{J}$. Rosenfeld, with fine accounts by P. Hughes of the blizzard of ' 88 and the 1900 Galveston hurricane. The chapter on "Unstable Lands" by S. L. Harris consists of 25 essays, descriptive and expository, discussing plate tectonics, earthquakes, tsunamis, and volcanoes. The final chapter, titled "Climatic Shifts," was contributed by M. H. Glantz and consists of 29 essays arranged under headings of climate variability, climate change, climate monitoring, and climate surprises.

Restless Earth is organized to encourage reading from front to back; however, each of the many essays is freestanding and can be read separately. Some are informative, interesting, and well written. Some are not. I found the historical accounts of specific events far better than the expository discussions that, too frequently, contain statements that are fragmentary, carelessly written, or confusing. For example, on page 100 it reads, "Thunderstorms are particularly good at banging airborne particles together, just like hydrogen bombs and volcanoes." On the other hand, there are intriguing historical insights. For example, Glantz suggests (p. 270) that Pizarro's conquest and the subsequent course of Peruvian history may have occurred only because the conquest coincided with El Niño.

The individual essays are short, ranging from about 1000 to 2000 words. Inevitably each is limited to elementary concepts and simple facts. This results in repetition that is often annoying, and at the same time it excludes enriching material that many readers would find interesting and stimulating. Some of the figure captions are incomplete, obscure, or inaccurate. In summary, the book could have benefitted from overview at an early stage and from critical editing.

Production of the book is of high quality, and the copy editing good. (Only one obvious typo was noted-on page 61 , line 4 "million" should be "billion.") The reasonable price and the excellent photographs make Restless Earth attractive as a coffee table book.-Robert G. Fleagle.
The Forgiving Air

Understanding Environmental Change Richard C. J.

Somerville

$\$ 13.95$ at bookstores or order 1-800-822-6657

University of California Press

www.ucpress.edu
Robert G. Fleagle is a professor of atmospheric sciences at the University of Washington, Seattle, Washington. 
Snow in America. Bernard Mergen. 1997. 321 pp. $\$ 24.95$. Hardbound. Smithsonian Institution Press. ISBN 1-56098-780-4.

Everyone has snow-related memories-the first flakes in November, a white Christmas, a few days off from school, or, for meteorologists, their first accurate - or blown - forecast. This book is for everyone. Mergen, a professor of American studies, has pursued with a passion the cultural and social meaning of "snow in America" for over a decade. The result is this handsome and insightful if eclectic book that examines snow from all angles. There are chapters on the early philosophies of snow, on snow shoveling, recreation, and the origins of modern snow science.

\section{Mergen's ultimate goal is to make sense of the ways in which nature and culture interact to create the world we inhabit.}

Mergen has set three goals for the book: "to discover past natural environments; see how technology has restructured human ecological relations; and show how perceptions, ideologies, ethics, laws, and myths have become part of an individual's or group's dialogue with the natural world" (p. xvi). Among New Englanders, winter weather was thought to be important in shaping strong character, while many other colonials argued strenuously that clearing and cultivation was moderating the harsh American climate. In songs and paintings, artists depicted winter scenes as either pastoral snowscapes or cruel deathtraps for the unwary or the unprotected. By 1890 , just as the western frontier was declared closed, meteorologists defined a new north-south "snow frontier" for the nation based on persistent winter snow cover.

The encounter between the snow and the industrial era was at best ambivalent. Snow storms had massive negative effects on the new transcontinental railroads and on developing urban infrastructures. By the 1920s snow-covered roadways, rather than being packed or rolled for horse-drawn sleighs, were now plowed, sanded, and salted for automobiles. Snow had become a major transportation hazard as well as a disposal problem. Recreational patterns also changed. While cross-country skiing languished, newly developed ski areas built lodges and condominiums for the affluent, deforested more mountainside trails, and erected massive mechanical lifts. Skiers began to expect then demand "designer snow" on the slopes. Downhill skiing-an expensive and environmentally marginal practice-surged in popularity. So did snowmobiling, a practice that transformed the hush of a winter snowfall into the buzz of two-cycle motors at full throttle.

Meteorologists may wish to focus on chapters 4 through 6, which document the scientific study of snow in the twentieth century, originating with the work of J. E. Church of the Sierras. The weather bureau, the forest service, the military, and the NSF were all involved in snow science and watershed hydrology. Zoologists, botanists, and ecologists had their own research agendas focused on the "snow commons."

The book ends with a poetic note, with "the modern minds of winter," a survey of twentieth century artistic and literary impressions of winter. Mergen's ultimate goal is to make sense of the ways in which nature and culture interact to create the world we inhabit. Paraphrasing a poem by Wallace Stevens, Mergen writes, "nature is the nothing that is there, while culture, art, and science are the nothing that is not." Nature thus constitutes an "unknowable world," while human representations are "endless approximations to it" (p. 210). Both are infinitely changeable. This may be a heady philosophical statement, but Mergen's enthusiasm for his subject makes it quite enjoyable. For experts or enthusiasts in the snowbelt or the sunbelt, this book is well worth the time. -James R. Fleming.

James R. Fleming is the director of the Science, Technology and Society Program at Colby College in Waterville, Maine.
Regional Frequency Analysis. J. R. M. Hosking and J. R. Walllis. 1997. 224 pp. \$69.95. Hardbound. Cambridge University Press. ISBN 0-521-43045-3.

Regional frequency analysis, as defined by the authors, is the process of using measurements of the same kind of data at several sites to estimate a frequency distribution. The aim of this monograph is to present a complete description of an approach, that is, "the specification of all necessary computations, a description of the theoretical statistical background, an assessment of the method's performance in plausible 
practical situations, recommendations to assist with the subjective decisions ... and consideration of how to overcome some of the difficulties often encountered in practice."

The approach taken by the authors is based on Lmoments, which are linear combinations of order statistics. Although the statistical theory behind L-moments has been developed over several decades, practical application in the environmental sciences has not been in the forefront of analytical techniques. Perhaps the reason for the lack of popularity of L-moments is that a unified treatise on the methodology has not been available.

I first became acquainted with the authors almost 10 years ago. During a planning meeting for a U.S. Army-sponsored drought study, J. Hosking and J. Wallis presented their L-moment-based, regional frequency approach. Although trained in statistics and climatology, I was completely unaware of L-moments. I then spent the next few months reading papers on L-moments and became convinced that the methodology was theoretically sound. After agreeing to use the methodology for the drought study, I worked with the authors to solve the practical problems of applying the theory to an analysis of precipitation data over the United States. I am admittedly biased, but I believe that the authors' approach is a viable technique for analyzing frequency distributions of environmental data.

The monograph is a mix of intuitive reasoning, statistical arguments, practical data considerations, caveats, recommendations, and liberal examples that are woven into a coherent, well-organized, easy-to-read book. The first chapter introduces the notion of regional frequency analysis and describes some of the conceptual considerations and premises. It also outlines the logical progression that the book will follow.

Chapter 2 introduces L-moments from the statistical viewpoint. The theoretical parts of this chapter are concise and may not be completely understood unless the reader has a good background in statistics. However, references are plentiful for the reader who wants to delve into the theory. For those not so inclined, there are several figures and examples that give the reader a good understanding of the concepts.

Chapters 3 through 6 discuss separate parts of the approach in logical order: screening data, identifying homogeneous regions, choosing frequency distributions, and estimating frequency distributions. Each of these chapters is organized the same way. First, general concepts are discussed from practical viewpoints of the importance of the subject matter and of defining the data analysis problems and assumptions. Second, heuristic arguments are given on ways to solve the problems. Third, formal definitions of statistical measures are presented. Fourth, the uses of the measures are described, and last, examples are given. In each of these chapters, the authors present caveats and recommendations.

Chapter 7 presents the results of extensive testing of the algorithms for the purpose of showing when the approach should and should not be used. The authors examined biases and variability of quantile estimates for variants of the estimation procedure, for aspects of the regional specification, and for violations of the assumptions of regional frequency analysis. They explore the performance of the approach under a wide range of conditions and neatly summarize their conclusions on one easily read page at the end of the chapter. The next chapter briefly discusses alternatives to the L-moment approach and shows either why these alternatives are inferior to the authors' method or how some of these alternatives can be meshed with their procedure.

Chapter 9 gives two examples of the methodology. The first one goes through all the steps and decisions that were made in the precipitation analysis that was done for the U.S. Army, and the second one goes through the process for an analysis of streamflow in a small area in central Appalachia. Both examples illustrate the practical utility of the approach.

For each of 11 frequency distributions that are commonly used in the environmental sciences, an appendix gives the form of the probability density function, the cumulative distribution function, the quantile function, and expressions for the L-moments in terms of the parameters and for the parameters in terms of the L-moments. The appendix also gives an approximate relationship between L-skewness and L-kurtosis, and an L-moment ratio diagram that can be used for comparing theoretical values to sample data. Numerical methods have been programmed as Fortran 77 routines that provide computations of the cumulative distribution functions, quantile functions, L-moments given parameters, and parameters given the low order L-moments for the distributions in the appendix (except the uniform distribution); of the probability weighted moments and L-moments of a data sample; of Ward's cluster analysis algorithms; of discordancy, heterogeneity, and goodness of fit measures; for fitting a distribution to a regional dataset; and for assessing the accuracy of regional estimates. The latest ver- 
sion of the software suite is available online from http:/ /lib.stat.cmu.edu/general/lmoments.

The authors have indeed achieved their aim. The book is an excellent treatise on a practical approach

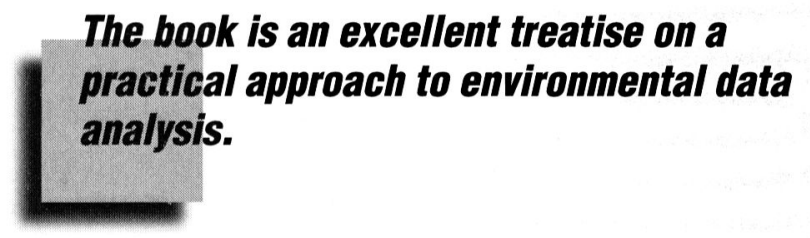

to environmental data analysis. It is logically organized to correspond to the routine steps a researcher would (or should) follow in analyzing data. Hosking and Wallis have described a complex subject in a simple and logical manner that can be understood by both the layman and the expert. Their arguments are theoretical and intuitive, and are supported by numerous examples, figures, and references. I highly recommend this book for all analysts not only for the Lmoment approach, but for the practical, conceptual, and philosophical concerns that are inherent to all analyses of environmental data. - Nathaniel B. Guttman.

Nathaniel B. Guttman is a statistical climatologist with the National Climatic Data Center, Asheville, North Carolina.
Computer Modeling of Seas and Coastal Regions III. J. R. Acinas and C. A. Brebbia, Eds. 1997. 442 pp. \$150.00. Hardbound. Computational Mechanics Publications. ISBN 1-853-12499-0.

This book represents the proceedings of the Third International Conference on Computer Modeling of Seas and Coastal Regions held in La Coruña, Spain, in June 1997. The conference was organized by the Wessex Institute of Technology, Southampton, United Kingdom, and Universidad de La Coruña, La Coruña, Spain, and was cochaired by J. R. Acinas and C. A. Brebbia. The objective of the conference was to provide a forum for the rapid dissemination and exchange of information on seas and coastal regions and their relationship to environmental problems. The primary focus of papers was on the development and application of models to address a wide variety of coastal environmental problems. The papers included in the book were reviewed by the conference's Scientific Advisory Committee prior to acceptance.

The book is divided into seven separate sections: shallow-water models, tidal simulations, estuarine problems, pollutant transport and dispersion, wave propagation, harbors and marinas, and sediment transport and coastal erosion. A total of 41 papers are presented with approximately five to nine papers per section. The sections on estuarine problems and harbors and marinas have the smallest numbers of papers at two and four, respectively. The paper authors are principally from Spain and the United Kingdom (about one half the total), with most of the remaining from Europe.
At the broadest level, the book suffers from a lack of focus and clear definition of which papers should be included and which should not. This is reflected in the organization of the different sections, the assignment of papers to a given section, and in the papers selected for publication. As an example of the organizational issue, several papers on storm surge simulations are included in the section in tidal simulation, while papers on tidal simulations are presented in the shallow-water section. While this is not a major problem, it is a distraction. A more serious problem is that there are a substantial number of papers (perhaps as many as 10 , or $25 \%$ of the total) that do not adhere to the coastal environmental modeling focus of the conference. As examples there are papers on measurements of coastal litter and waste pollution, wave propagation near the coast, wave flume dynamics, and morphodynamics of small estuarine river systems that have no modeling component. On the other hand, there are several papers that describe the development and application of models that appear well outside the central thrust of the conference. Examples include those on numerical modeling of nonlinear random wave forcing of offshore structures, variations of frictional resistance under long waves, and the simulation of the motion of berthed ships in harbors.

As is often typical of conference proceedings, the paper quality and level of development vary significantly. In several cases the papers are relatively routine, reporting on the application of well-known techniques to standard problems in various geographic areas. In other cases, new model developments are summarized and the application of state-of-the-art 
model systems presented. The papers in the book cover the entire range of modeling from fundamental developments to practical applications. Surprisingly, there are no papers on model visualization or animation techniques, nor on nowcasting or forecasting systems.

The strongest, most well-developed material in the book, with the largest number of papers, is in the area of hydrodynamic modeling with applications to tidal and wind-forced flow problems. Of particular note in this section are R. W. Barber et al.'s presentation of the development of a nonorthogonal boundary fitted coordinate hydrodynamic model and its application to wind-forced flows in the Gulf of Thermaikis, and papers by R. V. Pearson et al. and C. G. Mingham and D. M. Causon on the application of finite volume techniques to shallow-water flow dynamics. M. N. A. Mooij and M. Verlaan present an interesting paper on automated procedures for calibration of shallow-water models. Using the less traditional streamfunctionbased modeling approach, Y. R. Fares presents an application to multilevel circulation prediction in the Red Sea and adjacent waters. G. G. Tomasson et al. and P. Daniel present the results of storm surge modeling for Iceland and a variety of tropical waters, respectively.

In the pollutant transport modeling area, two of the most interesting papers are on high-resolution finite volume modeling by Mingham and Causon and comparison of Eulerian and semi-Lagrangian finite element solutions for the advective diffusion equation by F. X. Giraldo and B. Neta. The papers on wave propagation modeling deviate the most from the conference focus and are the most disparate in terms of quality. The most interesting papers, within the context of the conference focus, are by W. Luo and R. Flather on the nested nearshore wave modeling in the southern North Sea and by D. Aelbrecht on finite element mod- eling of wave dynamics in coastal areas and harbors.

The papers in the sediment transport modeling cover the range from conceptual models to the summary of an integrated series of models to assist in the design of beaches. The most fully developed work presented is J. M. de Kok and van de Meulen's threedimensional simulation of the hydrodynamics and transport of fine-grained suspended sediment at the entrance to Rotterdam Harbor. J. P. Sierra et al. and L. I. Portela also present useful papers on morphological modeling in the vicinity of nearshore coastal structures (groins and shore parallel breakwaters) and the effects on settling velocity on modeling of suspended sediment transport in the Tagus estuary.

In summary, about one-quarter of the papers in the book are outside the principal focus of the conference and cover a very broad range of nearshore topics. The papers on coastal hydrodynamics and pollutant transport are the most numerous, the best developed, and the most useful. The section on wave propagation is the weakest. Even though several of the papers are quite good, the section suffers from a lack of both breadth and depth. The section on sediment transport and coastal erosion is not particularly strong. While this book would be a useful addition to the coastal hydrodynamic modeler's library, it is not recommended for those principally interested in wave propagation or sediment transport modeling.-Malcolm Spaulding.

Malcolm Spaulding is a professor and chair of the Ocean Engineering Department at the University of Rhode Island, Narragansett, Rhode Island. He is an expert in the field of coastal and estuarine circulation and pollutant transport modeling. He has chaired or cochaired five international conferences on estuarine and coastal modeling over the past decade.
Biomass Burning and Global Change. Volume 1: Remote Sensing, Modeling, and Inventory Development, and Biomass Burning in Africa. Joel S. Levine, Ed. 1997. 551 pp. $\$ 80.00$. Clothbound. The MIT Press. ISBN 262-12201-4.

Biomass Burning and Global Change. Volume 2: Biomass Burning in South America, Southeast Asia and Temperate and Boreal Ecosystems, and the Oil Fires of Kuwait. Joel S. Levine, Ed. 1997.351 pp. $\$ 70.00$. Clothbound. The MIT Press. ISBN 0-262-12202-2.
Biomass burning is an important driver of global change, with large consequences for the buildup of greenhouse gases and aerosols, and depletion of stratospheric ozone and tropical deforestation. For example, carbon emissions from biomass burning accounts for $30 \%-80 \%$ of the fossil fuel burning rate of $5.7 \mathrm{Gt}$ of carbon per year. These two landmark volumes include 84 contributions on biomass burning by 250 researchers from 20 countries, the product of a Chapman Conference held in Williamsburg, Virginia, on 13-17 March 1995 and sponsored by the American Geophysical Union, the National Atmospheric and Space 
Administration, the Environmental Protection Agency, USDA-Forest Service, the International Geosphere-Biosphere Programme, and the International Global Atmosphere Chemistry Project. This was the second Chapman Conference on Biomass Burning, the first one was also held in Williamsburg in March 1990 and published by MIT Press (Levine 1991).

Biomass Burning and Global Change includes an impressive array of chapters, a must-have reference for anyone interested in biomass burning, atmospheric chemistry, and particularly the Tropics. Part I includes chapters on remote sensing via several satellite systems, including low-light images obtained with the Defense Meteorological Satellite Program (DMSP) Block 5 satellites, the National Oceanic and Atmospheric Administration's Advanced Very High Resolution Radiometer (AVHRR), geostationary satellites,

\section{Biomass Burning and Global Change includes an impressive array of chapters, a must-have reference for anyone interested in biomass burning, atmospheric chemistry, and particularly the Tropics.}

and astronaut photography from the space shuttle. Part II features models that address biogeochemistry and atmospheric transport and introduces new inventories of biomass density and gaseous and particulate emissions produced during burning. Part III reports several large-scale field fire experiments (SAFARI-92, TRACE-A, EXPRESSO in Africa and South America; SCAR-C in the Pacific Northwest; and the BOR Forest Island Experiment in Russia). The most salient finding from these experiments is that biomass burning produces significant amounts of methyl bromide $\left(\mathrm{CH}_{3} \mathrm{Br}\right)$, which is involved in the chemical destruction of stratospheric ozone. Volume 1 also compiles all of the chapters dealing with Africa. Volume 2 includes chapters on biomass burning research in Brazil, Southeast Asia, and temperate and boreal ecosystems. Volume 2 ends with three chapters on the oil fires resulting from Iraq's invasion of Kuwait, which produced an impressive flux of gaseous and particulate emissions into the atmosphere. If there is something missing from Biomass Burning and Glo- bal Change, it is a historical perspective. Surely, biomass burning as both a natural and anthropogenic phenomenon did not just begin in the 1980s. Aside from a couple of chapters, there is little consideration of historical data in the book.

In the biomass burning community, the greatest single challenge, according to Levine and other authors of these two volumes, is to accurately assess the spatial distribution of fires over a given period of time, that is, weeks, months, or years. Are we there yet? Well, maybe not, if we consider circumstances and ramifications of fires in Indonesia and the Amazon Basin during the present El Niño. Biomass burning varies greatly from year to year depending on whether it is a relatively dry (El Niño) or wet (La Niña) year in the Tropics, when people can slash-and-burn more or less than usual, respectively. Hypothetically, 1) the intensity of tropical biomass burning in a given year is predictable from the Southern Oscillation a few months in advance; such forecasts could be used by national and international authorities to reduce rates of tropical deforestation, as well as atmospheric loading of trace gases; 2) through its influence on tropical biomass burning, El Niño-Southern Oscillation (ENSO) affects year-to-year fluxes in carbon and other emissions; carbon fluxes may be sufficiently large to explain interannual variations in atmospheric $\mathrm{CO}_{2}$ that also covary with ENSO (Keeling et al. 1995); 3) an anomalously warm Pacific and persistent drought in the Tropics since 1976 have accelerated the rate of biomass burning and tropical deforestation; a return to a cold Pacific and wetter Tropics, such as persisted during the middle of this century, would naturally slow the pace of deforestation. Because fire statistics are nonexistent, covariance between tropical biomass burning at the global scale and the Southern Oscillation is assumed and not quantified.

One promising source of quantitative, historical information is the Global Area Coverage (GAC) images, from the AVHRR satellites, available on a daily basis at $5-\mathrm{km}$ resolution since 1981 , and at $1.1 \mathrm{~km}$ since 1984. Because of spatial and temporal (time of day) sampling, neither the number of fires or area burned can be derived directly from AVHRR GAC data. One disappointment of Levine's book is that the jury is still out on the use of the GAC data to compile meaningful and globally integrated fire statistics on daily, weekly, and yearly timescales; few of the practical problems enumerated by Robinson (1991) have been resolved. Given the volume of AVHRR data on 
a global and daily basis (probably 20 or more terabytes), both the technology and the funding present a formidable obstacle.

As Global Change and Biomass Burning indicates, a global fire product for change and trend analysis is very much in the minds of the biomass burning scientific community. Levine and the many authors of this book should be commended for a job well done and should be encouraged to set a global fire product as the main priority for the next Chapman Conference on biomass burning.-Julio Betancourt.
Julio Betancourt is a research scientist with the $\mathrm{Na}$ tional Research Program, Water Resources Division, U.S. Geological Survey, Tucson, Arizona.

\section{References}

Keeling, C. D., T. P. Whorf, M. Whalen, and J. van der Plicht, 1995: Interannual extremes in the rate of rise of atmospheric carbon dioxide since 1980. Nature, 375, 666-670.

Levine, J. S., Ed., 1991: Global Biomass Burning: Atmospheric, Climatic, and Biospheric Implications. The MIT Press, $536 \mathrm{pp}$.

Robinson, J. M., 1991: Fire from space: Global fire evaluation using infrared remote sensing. Int. J. Remote Sens., 12, 3-24.
The Earth and the Cosmos (The Legacy of Hans Ertel). Wilfried Schröder and Hans-Jürgen Treder, Eds. 1997. 382 pp. \$20.00. Paperbound. Science Edition. ISSN 0179-5658.

Hans Ertel was a German geophysicist and fluid dynamist whose career spanned the middle four decades of the twentieth century, during which time he published some 270 scientific papers. He is most

\section{The Hubble Wars \\ Astrophysics Meets Astropolitics in the Two-Billion- Dollar Struggle over the Hubble Space Telescope \\ ERIC J. CHAISSON}

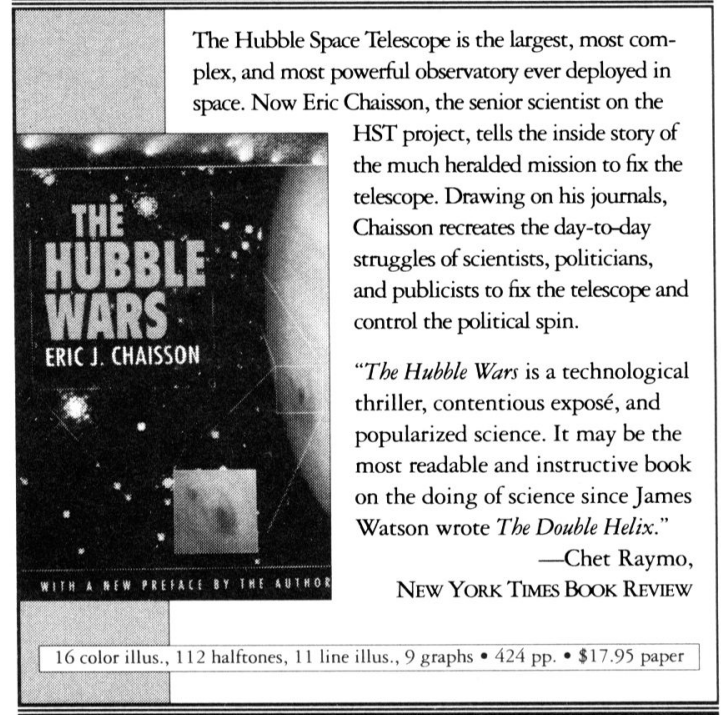

Harvard University Press $\begin{aligned} & 8004482242 \\ & \text { www.hup.harvard.edu }\end{aligned}$ widely remembered today for his discovery of a Lagrangian vorticity invariant for a stratified fluid, often referred to as the "Ertel potential vorticity." Schröder and Treder have compiled a biographical volume to celebrate Ertel's life and work. This is not a researched scientific biography by impartial scholars. It is a collection of historical materials, reprinted scientific papers, reminiscences, and some other odds and ends that have been compiled by two individuals with personal and scientific connections to Ertel, in the hope that it will "make Ertel's name better known in the international scientific community." The result is an idiosyncratic volume of poor production quality that will probably prove to be of the most value to those who already have a specific interest in Ertel.

The books contains an introduction, written by Schröder, and four chapters "Biographical Aspects," "Selected Papers," "Recollections of Hans Ertel by his Friends and Colleagues around the World," and "Hans Ertel and Alexander von Humboldt." Most of the material is either in German or English.

In the introduction, the opinion is expressed that Ertel's work has been undervalued and insufficiently recognized in the English-speaking scientific world and that this "seems to be due to the language barrier." Two specific claims are also made: 1) that in a 1940 publication, Ertel derived equations "equivalent to those which were published by Charney some years later in which Charney gave no acknowledgment to Ertel" (evidently meaning Charney's quasigeostrophic equations), and 2) that "Ertel derived, long before Rossby, the theory for what were later described as 'Rossby waves.'"

Chapter 1 contains a reprinted sketch of Ertel's life, a reprinted obituary (both originally written by 
Schröder), and a number of other items. These include a reprint of Ertel's thesis publication on geomagnetism and a correspondence between the mathematician Otto Neugebauer and publisher Julius Springer arranging the publication of Ertel's generally well-regarded 1938 book Methoden und Probleme der Dynamischen Meteorologie (Methods and Problems of Dynamical Meteorology).

Chapter 2 contains reprints of 17 of Ertel's scientific publications (often with the quality of photocopies, a texture that pervades the volume) and oneor two-sentence summaries (typewritten in English) of five more. Surprisingly, this collection does not include Ertel's original publications on the potential vorticity invariant, nor any article directly relevant to the specific claims of priority made in the introduction.

Chapter 3, "recollections" of Ertel, primarily contains copies (again photocopy quality) of letters written in answer to requests sent by Schröder and Treder to various individuals, including some internationally recognized scientists. Among these are $\mathrm{H}$. Stommel (who responded that he has never met Ertel but that his teacher C.-G. Rossby had thought highly of him), several pioneers of numerical weather prediction, and a number of other well-known fluid dynamists, meteorologists, and physical oceanographers. Many of these are thoughtful letters and can make an interesting read. Differing views are expressed on the issue of the "language barrier." One writer states that access to the German literature was limited during the war but returned to normal within a few years. Another writes that for many years after the war he and many others in his country "could not get themselves to read anything in the German language." One curious contribution to this section consists of a photograph of Ertel with Rossby and a reprinted obituary of Rossby that does not mention Ertel. (The friendship that developed between Rossby and Ertel is mentioned several times in other parts of the book.) Another consists of a single reprinted page of an article by J. G. Charney, on which a reference to Ertel's work is made in a footnote. But, however complicated the historical circumstances of Ertel's life and work may have been, a consistent picture of the individual emerges through these letters: the writers who knew Ertel all recall him with affection and respect.

Chapter 4 consists of material relating to Ertel's service as director of a commission of the Academy of Sciences of the German Democratic Republic that was formed in response to a proposal from Ertel, to commemorate the centennial of the death of the nine- teenth century German scientist Alexander von Humboldt. Most of this consists of a correspondence between Ertel and historian Hanno Beck, which seems to be primarily of relatively narrow historical interest. It is evidently included to illustrate Ertel's dedication to the institutions and individuals of science, which is reflected also by his record of administrative service as well as in the personal recollections by his friends and colleagues.

A detailed discussion of the two claims of priority, listed above, that are made in the introduction to the volume is best left to historians and is certainly beyond the scope of this review. However, a few remarks are in order. Remarkably, the cited publication by Ertel (Neue atmosphärische Bewegungsgleichen und ihre Anwendung auf die Theorie der Zyklonenbewegung, Annalen der Hydrographie und Maritimen Meteorologie, 1940, 68, 421-431) does include the derivation of a linear barotropic quasigeostrophic potential vorticity equation that predates Charney's quasigeostrophic theory by the better part of a decade. However, Ertel's physical understanding of this result seems to be limited. He does not identify it as a potential vorticity equation and devotes a section to the physical interpretation of the Laplacian of the pressure without recognizing the quantity to be the geostrophic vorticity. The linearization arises apparently by accident through an inconsistent scaling argument, and there is no indication of the possibility of a generalization to stratified flow. Thus, this contribution does not seem to match Charney's either in its clarity and generality of mathematical analysis or in its depth of physical insight. Perhaps more importantly, there is also, to my knowledge, no indication that Charney was aware of this paper by Ertel; he came to his quasigeostrophic theory by quite a different route, through his work on baroclinic instability. It seems unlikely that Charney's results depended on Ertel's in any way or that he purposefully neglected to give Ertel credit to which he might have been entitled. The second claim of the introduction appears to be contradicted by the content of this same paper. In it, Ertel applies his "new equations of motion" to the theory of cyclone motion and succeeds in rederiving by different means the barotropic beta-plane planetary wave dispersion relation. He attributes the original derivation of this dispersion relation to Rossby and Haurwitz, not himself (and, of course, Hough had beaten them all to it in spherical geometry, but that is another story).

The exaggerated claims made on the behalf of Ertel 
by the editors of this volume should not be allowed to detract from Ertel's genuine contributions, some of which have indeed been lost to the modern literature. Another example, in addition to the 1940 paper cited above, might be his 1939 formulation of a Lagrangian variational principle for a rotating, compressible fluid, which is not, to my knowledge, cited in any modern article or text on Hamiltonian fluid dynamics. (Similar, but more complete early results by Gustav Herglotz were also lost until the recent publication of a volume of his lecture notes, edited by R. Guenther and $\mathrm{H}$. Schwerdtfeger.) On the other hand, it seems possible, even likely, that Ertel's 1942 discovery of the general potential vorticity invariant for a stratified fluid was not entirely independent of Rossby's earlier work, as is often implied. Ertel visited Rossby at the Massachusetts Institute for Technology during 1937, after Rossby's potential vorticity first appeared in a 1936 publication; the MIT Meteorological Division is listed as Ertel's current affiliation in the preface to his 1938 book, cited above. The friendship between Ertel and Rossby dates from this period and includes a later collaborative publication on another vorticity invariant. It should be emphasized here that, whatever the true history of these ideas, it does seem clear that Rossby and Ertel were themselves satisfied with the published record of their respective contributions. Still, it would be ironic if the present volume, compiled to celebrate and commemorate Ertel's contributions, should eventually lead to a reappraisal that diminishes his role in the discovery for which he is most widely remembered today. But then the history of science, like the rest of history, is full of ironies.- - Roger M. Samelson.

Roger M. Samelson is an associate professor in the College of Oceanic and Atmospheric Sciences at Oregon State University. His research interests include coastal oceanography and coastal meteorology, large-scale ocean circulation, and the instabilities and nonlinear dynamics of geophysical fluids.
The Perfect Storm. Sebastian Junger. 1997. 227 pp. \$23.95. Hardbound. W. W. Norton \& Company. ISBN 0-393-04016-X.

Set in the fishing community of Gloucester, Massachusetts, the author spins a tale about the sword fishing boat the Andrea Gail and the lives of its crew. This is no ordinary work of fiction, in fact, the book is marketed as nonfiction with the subtitle A True Story of Men Against the Sea.

The general plot revolves around the Andrea Gail, which set to sea in late October 1991, plotting a course for the Grand Banks and the swordfish feeding in its cold waters. What happened to the Andrea Gail has happened to countless boats and crew in every fishing community around the world: crew and boat depart for fertile fishing waters, the sea claims the boat, women and children are left without husbands and fathers. A community mourns the loss of a handful of its citizens. The cycle repeats.

What is unique about this story is how Junger tells it. He has certainly made all attempts to present a plausible scenario of what could have happened to the boat and crew. Junger stated in an online interview that "This is as close as we're going to get to knowing what happened on the boat. This is all we know."

To determine what was actually known about the plight of the Andrea Gail, Junger poured over pub- lished material about the ship wreck and radio dialogues from the Andrea Gail to other ships; conducted personal interviews; spent time with the crew's surviving family members; interviewed meteorologists, fishermen, survivors of other boats who encountered similar situations, and ship builders; studied buoy numbers and compared them to the captains logs; as well as imagined what the crew from the Andrea Gail experienced at the point when they knew in their gut the sea would claim them.

To let the reader better understand this tragedy, and to build an element of suspense, Junger digresses through the first half of the book about the history of Gloucester, Massachusetts, the evolution of fishing boats and gear, and the consequences of overfishing and the resulting economics. Central to the story is the development of an unusually intense storm system in the shipping lanes south of Nova Scotia, with an equally unusual motion, leading to heroic efforts by seamen and rescuers to save ships and people, not all of which were successful.

In describing the overall synoptic events, the upper trough overtaking the southward moving cold front, the author does reasonably well for a nonmeteorologist, and he has obviously spent much time matching entries of ship's logs to buoy reports to produce a somewhat coherent blow-by-blow description of the storm, including the ingesting of a late 
season hurricane from the Bermuda area. However, at times the author does stumble, resulting in utterances such as ". . . and a nationwide system called the Limited Fine Mesh, a grid superimposed on a map of the country where the corners represent data-collection points. Twice a day hundreds of LFM balloons are released to measure ..." and talking of a fax chart showing the developing storm as " ... a tightly jammed set of barometric lines ..." His attempts at describing why storms form are rather pathetic, even to the point of ignoring the Coriolis effect (which is why they spin counterclockwise). If the meteorologistreader can neglect these oversights, then the book becomes enjoyable. However, there is an important lesson here in that most of what has been learned about cyclogenesis over the past few decades has not been getting out to the public and we face a great challenge for the years to come.

Suspended somewhere between fact and fiction, The Perfect Storm is by no means the perfect book. Although it has enjoyed a consistent presence on a number of nonfiction bestseller lists (ranked number 3 on the top 40 amazon.com bestseller list for 1997), the book is flawed with typographical errors, editing oversights, and choppy writing, as well as technical inaccuracies. And quite obviously, the story has a number of holes in it; hardly avoidable due to such a large amount of missing information.

The last third of the book is rather disappointing. Junger expended a lot of time and energy making the reader care about the crew of the Andrea Gail, yet he spent the latter portion of the book describing rescue attempts of other ships' crew, who readers had not encountered until this point.

In all The Perfect Storm is a suspenseful, quick read, enjoyable in spite of the grammatical and technical errors. Junger obviously cared deeply about his subjects and through his words has let the world know about the lives of men who choose to battle the sea for their very existence and how the sea sometimes wins.-Julie Burba and Stu Muench.

Julie Burba is the manager of news and publicity for the AMS.

Stu Muench is a technical editor for the Journal of the Atmospheric Sciences for the AMS.

\section{Col. Holzman Presented The Robert M. Losey Award, 1947}

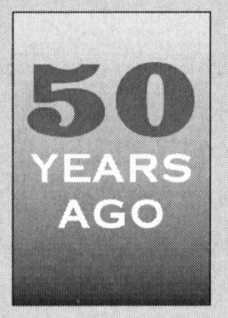

Established by the Institute of Aeronautical Sciences in 1940, this award honors the memory of Capt. Robert Moffatt Losey, a meteorological officer at the Air Corps, who was killed at Dombas, Norway, April 21, 1940, while serving as an official observer for the U.S. Army. He was the first officer in the service of the United States to die in World War II. For 1947, it was presented at the annual meeting of the Institute on January 1948 to Col. Benjamin G. Holzman, U.S.A.F., "In recognition of outstanding contributions to the science of meteorology as applied to aeronautics."

Colonel Holzman received his meteorological education at the California Institute of Technology, which awarded him the degree of Master of Science. During the period he also was Meteorologist for Eastern Air Lines (1934-1935); Meteorologist in Charge, American Air Lines (1935-36); Assistant Meteorologist, Soil Conservation Service (1936-1940); Teaching Fellow, Cali- fornia Institute of Technology (1937-1938); and Supervising Forecaster, U.S. Weather Bureau, at La Guardia Field 1940-42. During the war, Colonel Holzman served as Senior Forecaster for the U.S. Strategic Air Forces and had important responsibilities of a meteorological nature in connection with the bombing and invasion of Europe. Shortly after the close of the war, he was assigned to handle the meteorological problems connected with the Bikini atomic bomb experiments. His professional and technical accomplishments on this assignment gained him wide recognition from the Army and Navy personnel who were in charge of the experiment.

In his present position, Colonel Holzman not only has continued to make important contributions himself but also has initiated and guided many important meteorological investigations and had an important part in the successful formulation of the joint Weather Bureau, Army, Navy, and National Advisory Committee for Aeronautics Thunderstorm Project.

Bull. Amer. Meteor. Soc., 29, 218. 


\section{new publications}

Tectonic Uplift and Climate Change (William F. Ruddiman, Ed., 1997, 500 pp., \$115.00, hardbound, Plenum Publishing, ISBN 0-306-45642-7). This upto-date volume is a multidisciplinary effort to summarize the current state of a new hypothesis gaining increasing acceptance in geoscience circles: long-term cooling and glaciation are mainly controlled by plateau and mountain uplift through their effects on the carbon cycle and atmospheric $\mathrm{CO}_{2}$. Researchers in fields of geology, geophysics, atmospheric sciences, geochemistry, sedimentation/geomorphology, paleoceanography, and paleobotany present data and models that address and evaluate this premise. Some of the topics covered include changes in the position of the jet stream and westerly winds, the creation of monsoon circulations that focus heavy rainfall on the margins of uplifted terrain, formation of permanent ice sheets over Antarctica and Greenland, and the development of sea-ice cover in the Arctic Ocean.

Heat Transfer-Baltimore 1997 (M. S. El-Genk, Ed., 1997, 346 pp., $\$ 80.00$, paperbound, American Institute of Chemical Engineers, ISBN 0-8169-0739-0). A symposium on heat transfer was held in Baltimore, Maryland, in August 1997 and the 32 papers presented were compiled into Vol. 93 of the AIChE Symposium Series. These papers (all peer-reviewed) largely concern engineering heat transfer problems in areas such as nuclear reactors and waste management, and medical technology, most of which are somewhat removed from common heat transfer problems in the environmental sciences. The book also contains papers on new developments with thermoelectric and thermoacoustic devices that may have application to meteorological and oceanographic instrumentation. Each of the papers is self-contained with an abstract, text, illustrations, and references.

Mathematical Models in the Applied Sciences (A. C. Fowler, 1997, 402 pp., \$37.95, paperbound, Cambridge University Press, ISBN 0-521-46703-9). This book covers the increasingly broad field of numerical modeling at a fairly technical level and could be used as a text for a graduate course. To that end, exercises have been included, but the author has cautioned that they are purposefully difficult. There are 20 chapters, broken into five parts, with the first part serving as an introduction to mathematical modeling. The next part covers nondimensionalization, asymptotics, and perturbation methods, while the third part covers classic methods including heat transfer, viscous flow, solid mechanics, and electromagnetism. Parts 4 and 5 deal more specifically with applications that apply to a wide area of subjects from enzymes, to spruce budworms, to groundwater, to alloy solidification, to respiratory control, and to soil frost heaves. Familiarity with vectors and differential equations is assumed.

Annual Review of Fluid Mechanics (J. Lumley, M. Van Dyke, and H. Reed, Eds., 1998, 750 pp., \$60.00, clothbound, Annual Reviews, ISBN 0-8243-0730-5). This book is the 30th in a series of annual reviews of recent work in the field of fluid mechanics, presenting some 21 contributed papers written by 40 authors. Each paper is self-contained with an abstract, key words, and references (including author e-mail address). The book starts with a preface devoted to the contributions of L. F. Richardson to "mathematics, meteorology and models of conflict." The papers cover a variety of topics, many relating to aviation, while others include astrophysics, boiler heat transfer, flow over hills, sailing vessel design, and turbulent flames. This would be of use to anyone wishing to keep abreast of developments in the broad field of fluid mechanics.

Argument in the Greenhouse (N. Maybey, S. Hall, C. Smith, and S. Gupta, 1997, 442 pp., \$24.99, paperbound, Routledge, ISBN 1-415-14909-6). The expertise and experience of the authors is primarily in the field of economics and thus this book focuses on the economic and political aspects of the global warming issue rather than scientific aspects. In particular, strategies for abatement of the anthropogenic greenhouse gases are addressed, qualitatively and quanti- 
tatively at the international level. The book is divided into four parts, starting with an introduction to the problem of greenhouse gases and global warming and international policy issues, with the last part presenting summary and conclusions. In the second part, economic models of greenhouse gas control and energy pricing are reviewed along with application to a developing country (India). Optimal climate change policy and abatement strategy are subjects of the third part as well as economic and political aspects of "carbon taxes." This book is aimed at those involved or interested in issues associated with the abatement of greenhouse gases at an international level. It requires more of a background in economics (including calculus and statistics) than atmospheric sciences.

Chemical Abstracts on CD-ROM (1997, \$7500 for subscription, Chemical Abstract Service). The placement of Chemical Abstracts on CD-ROMs represents a modernization step to provide users with a fast, flexible search and browse capability (and reduced shelf space). As in the printed edition, bibliographic citations and abstracts are available, including structure diagrams and keyword indexes. The subscriber receives cumulative monthly updates containing all the year-to-date information. Indexes are included that are equivalent to printed indexes. The Chemical Abstract Service also produces CD-ROMs of Collective Indexes for 1987-1991 and Collective Indexes for 1992-1996. In addition, there is a CD-ROM for the Chemical Abstracts Service Source Index (1907-1996 plus 1997 updates). All CD-ROMs are IBM and Macintosh compatible, requiring $8 \mathrm{Mb}$ of RAM and "appropriate number of CD-ROM drives."

Radar Technology Encyclopedia (D. Barton and S. Leonov, Eds., 1997, 511 pp., \$528.00, hardbound, Artech House, ISBN 0-89006-893-3). This is a comprehensive radar encyclopedia, containing about 5000 entries from "absorber, radar" to "zone, radar," with numerous illustrations, tables, and mathematics used to define and describe the entries. Seven noted radar experts from Canada, the United States, and the former Soviet Union contributed up-to-date information for this international effort. Standard IEEE definitions have been used extensively. Articles and subarticles contain abbreviated references, and a complete 22-page bibliography is found near the end. The book also includes five pages of abbreviations and acronyms related to radar technology. The emphasis of

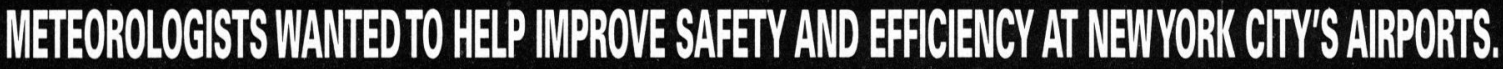

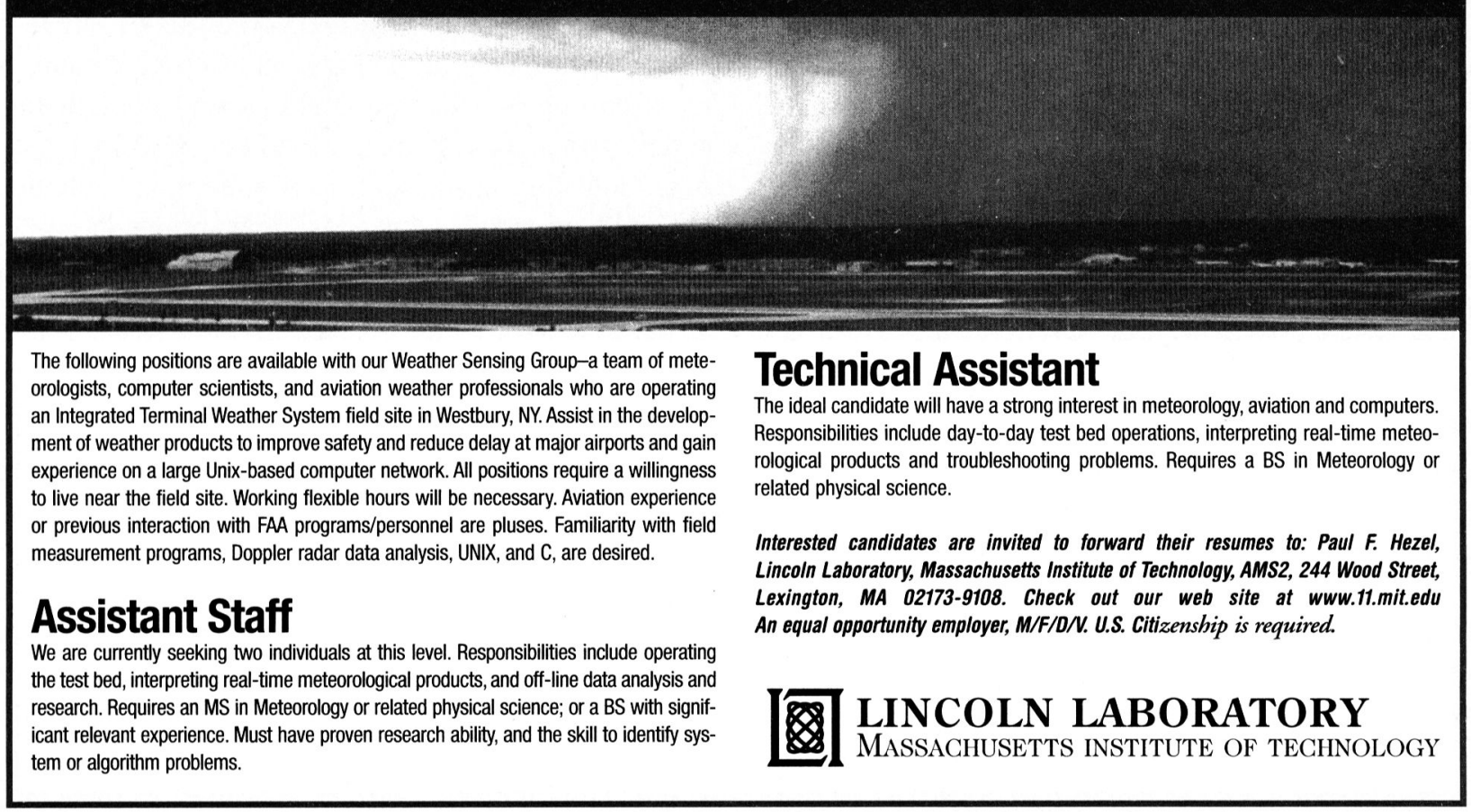


the book is on radar hardware, signals, and signal processing, with relatively brief entries on atmospheric effects.

Citadel of Ice: Dakshin Gangotri. The First Indian Wintering in Antarctica (Satya S. Sharma, 1997, 280 pp., \$-unavailable, hardbound, New Age International, ISBN 81-224-1020-0). This book deals with India's epoch-making, daring scientific adventure in the ice continent of Antarctica. It narrates the story of a group of 12 scientists and soldiers who contributed in establishing the first-ever wintering Indian base, Dakshin Gangotri, on a floating ice shelf. Beginning with the voyage to Antarctica by ship, the text details the process of constructing the base and the psychological and biological struggles involved. Written by the leader of the team, the book is illustrated with over 45 colored photographs and maps, and highlights the dogmatic determination of the team in pursuing research that began a new chapter in India's polar science.

Environmental Change and Challenge: A Canadian Perspective (P. Dearden and B. Mitchell, 1998, 565 pp., \$85.00, hardbound, Oxford University Press, ISBN 0-19-541014-9). The Canadian environment, containing vast resources of water, soil, forests, minerals, and wildlife, has been changing in past years through the actions of a growing and more demanding population. This large format book describes the use and misuse of resources that has led to the environmental changes. There are 22 chapters, each containing questions and suggested reading. The chapters are divided into five parts, starting with environment and resources, the ecosphere (with a section on climate change), management strategy, management in Canada, and the challenge for the future as provided by a closer look at forestry in the Clayoquot Sound area. The book is nontechnical, well illustrated (many in color), and written as a university text in environmental science (particularly for Canadian students). Many aspects of the environmental problems are covered and though the emphasis is on Canada, much is of a universal nature (even political aspects), which makes this interesting material for readers worldwide.

Mathematical Techniques, Second Edition (D. W. Jordan and P. Smith, 1997, 788 pp., \$95.00, hardbound, Oxford University Press, ISBN 0-19856462-7). This book is subtitled "An Introduction for the Engineering, Physical and Mathematical Science" and covers the broad spectrum of mathematics used in problem solving. Basic tools are covered in 21 chapters of the first three parts, starting from algebra and trigonometry, to vectors, differential and integral calculus, and matrix algebra. Transforms are covered in Part IV, multivariable calculus in Part V, and discrete mathematics in Part VI. Probability and statistics are in Part VII and the book concludes with applications projects (using Mathematica symbolic computations). The book could be used as a text for any of several undergraduate mathematics or applied mathematics courses, and each of the 40 chapters contains problems, with answers at the back of the book. There are eight appendixes that cover rules, definitions, and tables, which are useful for solving problems.

Climate Process \& Change (E. Bryant, 1997, 209 pp., $\$ 59.95$, paperbound, Cambridge University Press, ISBN 0-521-48440-5). Edward Bryant, a professor of geosciences, has written a concise yet comprehensive description of the processes involved in climate change and the potential impact on people and plant life. The book starts with a background on the "greenhouse" effect of carbon dioxide for Mars, Venus, and Earth and the evolution of Earth's climate. Three parts follow: the first considers the processes that affect climate, such as planetary geometry and radiation, atmospheric transports by weather systems, and oceanic processes and interactions. The second discusses the climate changes over the past million years, particularly the main glacial epochs, and looks at natural causes as well as human effects on climate. The last part goes into the potential impact of climate change due to carbon dioxide doubling on human health and on the earth's ecosystem. The book ends with an epilogue considering the forcing of greenhouse factors and a related analysis of land-ocean-atmosphere interactions favoring ice ages. Data sources are listed, including many World Wide Web addresses.

Principles of Gas-Solid Flows (L.-S. Fan and C. Zhu, 1997, 557 pp., \$85.00, hardbound, Cambridge University Press, ISBN 0-521-58148-6). The title will typically bring to mind industrial applications such as pulverized coal combustion, mineral powder processing, and sand blasting, but the authors have pointed out that there are also applications to natural phenomena such as dust storms, blizzards, and avalanches. Thus, much of the book is nonspecific with wide applications in mind. The first of two parts covers solid particles and their properties, collision mechanisms, 
momentum and heat transfer, and modeling. The second part is more industrial-oriented, covering gassolid separation, hopper flows, fluidizing beds, and conveyer systems. The book is quite technical, requiring a background in physics and math, and is suitable as a text, with chapters containing problems, references, and nomenclature.

Climates of the British Isles: Present, Past and Future (M. Hulme and E. Barrow, Eds., 1997, 454 pp., $\$ 110.00$, paperbound, Routledge, ISBN 0-415-130174). For those interested in the climate of the British Isles, be it over the geologic past or recent history or the coming future, this could be a book of interest. It is largely nontechnical and descriptive, with many illustrations, figures, and color maps of climate data. Some 28 different authors have written the 16 chapters, which are arranged into four parts. The book starts by introducing the concept that climate has always been changing and the first part goes on to describe the British Isles's climate in terms of weather systems. The next part reconstructs the past climate (and how it was determined) over the geologic past, including various glacial periods. In the third part are a number of chapters treating the climate and weather as recorded over the past few hundred years. Finally, the book presents numerical models and their predictions, the greenhouse effect, and the predictions of some models for the next hundred and even thousands of years.

\section{Fundamentals of the Physical Environment, Second} Edition (D. Briggs, P. Smithson, K. Addison, and K. Atkinson, 1997, 555 pp., \$35.00, paperbound, Routledge, ISBN 0-415-10891-8). The first edition was written as Fundamentals of Physical Geography and this text (large format) has been extensively rewritten and expanded to include new knowledge. However, it maintains its original purpose as an introductory text for the earth sciences. This descriptive book treats all the disciplines of the environmental sciences and includes not only the interactions between disciplines, but also interactions with humankind. There are 28 chapters that cover a wide range of topics including geology, oceanography, meteorology, climatology (and climate change), hydrology, glaciology, soil technology, ecology, and chapters with specific application to the environments of polar regions, mountains, drylands, the Mediterranean, and the moist Tropics. Each chapter includes many fig-

\section{New Alddlitionis tto AIMIS's Welb Sitte}

The AMS updates its Web site with new information monthly. We hope our membership and others interested in AMS will regularly go to the site to obtain the latest information on meetings, journals, chapters, AMS contacts, the monthly AMS Newsletter, and other information. In the past few months, we have added a number of new items. These are as follows.

- Subscribe to AMS Newsletter listserv

May 1998 AMS Newsletter

AMS Journals Online

Earth Interactions Online

May AMS Employment Announcements

Online Abstract Submission

- Draft Report of AMS ad hoc Committee on Certification
- The 27th Conference on Broadcast Meteorology

- The AMS Conference on Cloud Physics

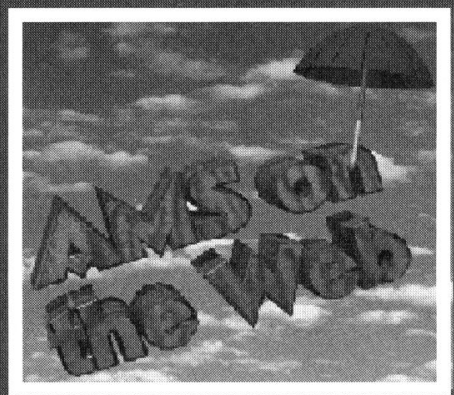

http://www.ametsoc.org/AMS 
ures (some color) with annotated references for future reading, and there is also a 24-page glossary.

Assessing Climate Change: Results from the Model Evaluation Consortium for Climate Assessment (Wendy Howe and Anne Henderson-Sellers, Eds., 1997, 418 pp., \$140.00, hardbound, International Publishers Distributor, ISBN 90-5699-067-5). Presenting the findings of an international, industry-sponsored global climate research group, the Model Evaluation Consortium for Climate Assessment (MECCA), this book focuses on the impact-oriented needs of policy makers and the private sector. It gives an overview of how climate change predictions are affected by the use of different model types, including ocean, atmosphere, sea-ice, and land-surface schemes. The impacts of climate change on many sectors-among them vegetation, severe weather, and agricultural productivity - are assessed. Intended as a reference book for researchers in climate change, this book will provide the international policy community with the context underpinning the current range of climate range predictions.

Through all the Changing Scenes of Life: A Meteorologist's Tale (Hubert Lamb, 1997, 274 pp., $\$$ - free, paperbound, Taverner Publications, ISBN 1901470-02-4). This is an autobiography of the English meteorologist-climatologist Hubert Lamb (grandson of hydrodynamist Horace Lamb) from his early school years of the 1920s to his establishment of the Climate Research Unit at East Anglia in 1972. His career was varied, though mostly within the British Meteorological Office, serving as aviation meteorologist during World War II, a tour on a whaling ship, and other duties in postwar Germany and Malta. The book contains many anecdotes, some meteorological, as well as encounters with important meteorologists of the day, such as Doporto, Sutcliffe, and Scherhag. While more of a recreational book, this can provide background information on applied meteorology in the middle twentieth century (for those not fortunate to have a meteorologist as a parent).

Applied Climatology: Principles and Practice (R. Thompson and A. Perry, Eds., 1997, 352 pp., \$100.00, hardbound, Routledge, ISBN 0-415-14100-1). There have been a number of recent books on climatology and climate change, but what tends to set this book apart is the emphasis on effects and interaction with the many forms of life on this planet. There are 25 contributed papers that have been divided into five parts covering research tools, physical/biological environments, cultural environment, changing climate, and an overview. Individual chapters all relate to climate but are diverse in nature, with topics such as hydrology, soil, vegetation, animal response, town planning, commerce, energy, and so on. The book is nontechnical and is written as an up-to-date undergraduate text on applied climatology. Numerous diagrams and illustrations are included.

From Calculus to Chaos (D. Acheson, 1997, 269 pp., $\$ 65.00$, hardbound, Oxford University Press, ISBN 019-850257-5). This is basically a textbook on dynamics- "how and why things change." The author has adapted a fresh approach, with the aim of making the application of calculus to problems in dynamics easier to understand and, hopefully, enjoyable. The book starts with reviews of calculus, differential equations, and numerical (computer) methods. The following chapters cover oscillating solutions, planetary motion, waves, fluid motion, and "chaos." The chapters are full of illustrations (including some of historic value) and contain exercises for the students with solutions toward the end of the book. Some knowledge of calculus is assumed, and readers can take full advantage of computer routines in the book if they have access to a PC with QBasic software. The book is quite suitable as a text in dynamics and can serve as a refresher for those wishing to see how applied math courses they struggled through can be made simple.

Hot Talk, Cold Science: Global Warming's Unfinished Debate (S. Fred Singer, 1997, 110 pp., \$14.95, paperbound, The Independent Institute, ISBN 0945999-75-5). The author brings his familiarity with the scientific literature-including studies overlooked-to review scientific, economic, and policy issues on the debate of global warming. Both lay readers and specialists will profit from the concise discussion of the climate record; computer models; the effects of clouds, oceans, aerosol cooling, solar variability, and greenhouse gases; crop yields; climate change mitigation; and much more. Far from showing a consensus, Singer argues that climate science does not support global-warming pessimism. 


\section{WMO publications}

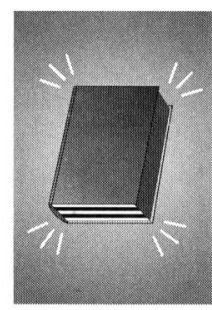

Weather and the Media: A Press Relations Guide (1997, 23 pp., \$20.00, paperbound, WMO No. 861, World Meteorological Organization, ISBN 92-6310861-7). It is primarily through newspapers, magazines, wire services, radio, and television that the WMO reaches the public. The importance of building partnerships with the media and the instrumental role played by official spokespersons in this process is emphasized here. The purpose of this booklet is to serve as a practical guide for Information and Public Affairs focal points of the National Hydrological Services of WMO member countries as well as for senior WMO staff who may have to deal with representatives of the media in the course of their work.

Climate, Drought and Desertification (1997, 12 pp., $\$ 20.00$, paperbound, WMO No. 869, World Meteorological Organization, ISBN 92-63-10869-2). This booklet explains the interaction between climate, drought, and desertification, and WMO's contribution to addressing these scourges. It was prepared on the occasion of the first session of the conference of the parties to the United Nations Convention to Combat Desertification, which marks an important milestone in humanity's struggle against drought and desertification. The contents of this guide are designed to enhance the understanding of decision makers, the media, and the public to some of the issues involved so that they can be addressed knowledgeably.

Stepping Forward: Implementation of the WMO CLIPS Project (1997, 12 pp., \$20.00, paperbound, WMO No. 863, World Meteorological Organization, ISBN 92-63-10864-1). The primary objective of the Climate Information and Prediction Services (CLIPS) project is to develop the capacity of the National Meteorological and Hydrological Services to take advantage of the recent advances in the science of climate and in the processing and delivery of climate information, and to pass on the benefits of the improved climate services to the user community. The purpose of this brochure is to outline the implementation of CLIPS.

\begin{abstract}
Mobilizing Resources for Technical Cooperation (1997, 24 pp., \$20.00, paperbound, WMO No. 864, World Meteorological Organization, ISBN 92-6310863-3). The WMO is committed to assisting countries to find appropriate solutions to pressing environmental and socioeconomic problems. Through its Technical Cooperation Programme, WMO assists its members, particularly developing countries and countries with economies in transition, to improve their national meteorological and hydrological services (NMHSs), so that they can contribute efficiently to sustain development activities. This brochure contains information for WMO member countries, and in particular their NMHSs, on the potential sources of funding of technical cooperation activities and how they can be tapped.
\end{abstract}

WMO and Climate Change (1996, 20 pp., \$20.00, paperbound, WMO No. 848, World Meteorological Organization, ISBN 92-63-10848-X). The global climate change issue, including the potential threat of serious disruption to socioeconomic activities, has been the focus of WMO for the past several decades. To ensure the comprehensive assessment of climate change, its impacts, and response measures, WMO together with the United Nations Environment Programme established the Intergovernmental Panel on Climate Change. This booklet summarizes the joint efforts promoting international actions that have led to current understanding of the importance, as a global resource, of the atmosphere in general and the climate in particular.

Commission for Basic Systems. Eleventh Session (1997, 106 pp., \$33.00, paperbound, WMO No. 854, World Meteorological Organization, ISBN 92-6310854-4). The 11th session of the Commission for Basic Systems was held in Cairo from 28 October to 7 November 1996 at the invitation of the government of Egypt. This abridged final report contains the general summary of the session and all activities of the session with resolutions and recommendations. 


\section{'Publishers' Addresses}

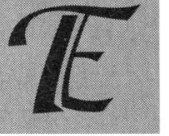

ditor's Note: Readers who are interested in purchasing any of the titles listed in the 1998 Book Supplement may do so through the addresses provided. Due to several member requests, the 1998 list of publishers' addresses includes phone numbers. The Bulletin staff has done its best to provide complete and correct addresses and phone numbers for our readers' convenience. Questions about books or publishers may be directed to the Production Editor, AMS, 45 Beacon St., Boston, MA 02108; telephone: 617-227-2426, ext. 233; e-mail: rthomas@ametsoc.org.

Academic Press, 525 “B” St., Suite 1900, San Diego, CA 92101; Telephone: 619-231-0926

Addison Wesley Longman, One Jacob Way, Reading, MA 01867; Telephone: 617-944-3700

Aeon Verlag \& Studio, P.O. Box 1108, 63401 Hanau, Germany; Fax: +49 6181/25 7954

Agrometeorological Applications Associates, B.P. 102, F-01213 Ferney-Voltair, France; Fax: 01133 450408842

American Institute of Chemical Engineers, 345 East 47th St., New York, NY 10017; Telephone: 212-705-7657

Annual Reviews, 4139 El Camino Way, Palo Alto, CA 94303; Telephone: 800-523-8635

Artech House, 685 Canton Street, Norwood, MA 02062; Telephone: 800-225-9977

Australian Bureau of Meteorology, GPO 1289K, Melbourne 3001, Australia; Fax: 03-669-4558

BasicBooks, 10 East 53rd St., New York, NY 10022; Telephone: 212-207-7522

Battelle Press, 505 King Ave., Columbus, OH 43201; Telephone: 614-424-6393

Briarpatch, P.O. Box 604, Short Hills, NJ 07079; Telephone: 201-376-7002

Cambridge University Press, 40 W. 20 St., New York, NY 10011; Telephone: 800-221-4512

Carolrhoda Books, 1241 First Ave. North, Minneapolis, MN 55401; Telephone: 800-328-4929

Chapman \& Hall, 115 Fifth Ave., 4th Fl., New York, NY 10003; Telephone: 800-842-3636

Chemical Abstracts Service, 2540 Olentangy River Rd., P.O. Box 3012, Columbus, OH 43210
Chip Taylor Communications, 15 Spollett Drive, Derry, NH 03038-5728; Telephone: 603-434-9262

Computational Mechanics, 25 Bridge St., Billerica, MA 01821; Telephone: 781-667-5841

CRC Press LLC, 2000 Corporate Blvd. NW, Boca Raton, FL 33431; Telephone: 561-994-0555

CSIRO Publishing, P.O. Box 1139, 150 Oxford St., Collingwood, VIC 3006 Australia; Telephone: 613 0396627666

A. Deepak Publishing, 101 Research Dr., Hampton, VA 23666; Telephone: 757-865-0332

Dover Publications, 31 E. Second St., Mineola, NY 11501; Telephone: 800-223-3130

ECW Press, 140 Commerce St., P.O. Box 120261, East Haven, CT 06512; Telephone: 800-805-1083

Elsevier Science, 655 Avenue of the Americas, New York, NY 10010; Telephone: 212-989-5800

European Centre for Medium-Range Weather Forecasts, Shinfield Park, Reading/Berkshire RG2 9AX, United Kingdom; Telephone: 44118949 9000

Gordon and Breach Science Publishers, 270 8th Ave., New York, NY 10011; Telephone: 212-206-8900

Gustav Fischer Verlag, Postfach 7201 43, D-70577 Stuttgart, Germany; Telephone: unavailable.

Harvard University Press, 79 Garden St., Cambridge, MA 02138; Telephone: 617-495-2600

The Independent Institute, 100 Swan Way, Oakland, CA 94621-1428; Telephone: 510-632-1366

International Publishers Distributor, P.O. Box 90, Reading RG1 8 JL, United Kingdom; Telephone: unavailable 
The Johns Hopkins University Press, 2715 N. Charles St., Baltimore, MD 21218; Telephone: 410-516-6900

Kendall/Hunt Publishing, 4050 Westmark Dr., Dubuque, IA 52002; Telephone: 800-228-0810

Kent State University Press, P.O. Box 5190, Kent, OH 44242; Telephone: 330-672-7913

Kluwer Academic Publishers, 101 Philip Dr., Norwell, MA 02061; Telephone: 617-871-6600

Lerner Publications, 241 First Ave. N., Minneapolis, MN 55401; Telephone: 800-328-4929

The McGraw-Hill Companies, 1221 Avenue of the Americas, New York, NY 10020; Telephone: 212512-2000

Minerva Press, 195 Knightsbridge, London SW7 1RE, United Kingdom; Telephone: 01712253113

The MIT Press, 5 Cambridge Ctr., Cambridge, MA 02142; Telephone: 800-356-0343

National Geographic Society, 114517 St. NW, Washington, DC 20036; Telephone: 202-857-7000

New Age International, 4835/24, Ansari Rd., Darya Ganjm New Delhi 110 002, India; Telephone: unavailable.

W. W. Norton \& Co., 500 Fifth Ave., New York, NY 10110; Telephone: 800-233-4830

Oxford University Press, 198 Madison Ave., New York, NY 10016; Telephone: 212-726-6000

Plenum Publishing, 233 Spring St., New York, NY 10013; Telephone: 800-221-9369

Prentice Hall, One Lake St., Upper Saddle River, NJ 07458; Telephone: 201-236-7139

Random House, 201 E. 50 St., New York, NY 10022; Telephone: 800-726-0600

Routledge, 29 W. 35 St., New York, NY 10001; Telephone: 212-244-3336

The Royal Danish Academy of Sciences and Letters, H.C. Andersens Blvd. 35, DK-1553 Copenhagen V. Denmark; Telephone: unavailable
RSMAS/University of Miami, 4600 Rickenbacker Causeway, Miami, FL 33149; Telephone: 305-3614000

Science Edition, Hechelstrasse 8, D-28777 Bremen, Germany; Telephone: unavailable

Smithsonian Press, 470 L'Enfant Plaza, Rm. 7100, Washington, DC 20560; Telephone: 800-782-4612

Southern Illinois University Press, Box 3697, Carbondale, IL 62902-3697; Telephone: 618-4532281

Spectroradiometry Consulting, P.O. Box 2747, La Plata, MD 20646; Telephone: 301-934-6364

Springer-Verlag, 175 Fifth Ave., New York, NY 10010; Telephone: 212-460-1500

Taverner Publications, c/o Climatic Research Unit, University of East Anglia, Norwich, NR4 7TJ, United Kingdom; Telephone: unavailable.

Taylor \& Francis Publishers, 1900 Frost Rd., Suite 101, Bristol, PA 19007; Telephone: 800-821-8312

University Press of Florida, 15 Northwest 15th St., Gainsville, FL 32611; Telephone: 352-392-1351

University Science Books, 55D Gate Five Rd., Sausalito, CA 94965; Telephone: 415-332-5390

University of South Carolina Press, 937 Assembly St., Carolina Plaza, 8th fl., Columbia, SC 29208; Telephone: 803-777-5243

Visible Ink Press, 835 Penobscot Bldg., Detroit, MI 48226; Telephone: 800-7766265

Water Resources Publications, P.O. Box 260026, Highlands Ranch, CO 80163; Telephone: 303-7419071

John Wiley \& Sons, 605 Third Ave., New York, NY 10158; Telephone: 212-850-6000

Whirlwind Books, RR3, Elmwood, ON NOG 1S0, Canada; Telephone: 519-363-5785

World Meteorological Society, (International orders only) C. D. 2300, CH-1211 Geneva 2, Switzerland; Telephone: 41227308478 (Domestic orders should be placed through AMS)

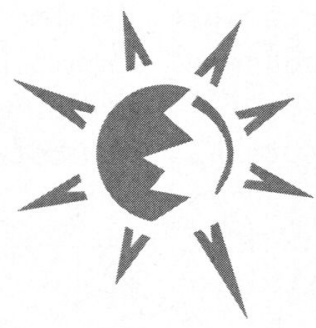

